Article

\title{
Fostering and Planning a Smart Governance Strategy for Evaluating the Urban Polarities of the Sardinian Island (Italy)
}

\author{
Chiara Garau*(D), Giulia Desogus and Mauro Coni \\ Department of Civil and Environmental Engineering and Architecture, University of Cagliari, \\ 09123 Cagliari, Italy \\ * Correspondence: cgarau@unica.it; Tel.: +39-070-675-5565
}

Received: 26 July 2019; Accepted: 6 September 2019; Published: 11 September 2019

\begin{abstract}
The interrelations between cities, inland areas, connecting road networks, urban, and political polarities have evolved, thereby determining economic, social, and place-based impacts. Thus, via a case study of Sardinia island (Italy), this study analyses regional transport data to evaluate the interrelations and mobility issues between the main cities and the settlement geographies of internal areas with a predominantly agricultural vocation. First, it frames the problems (common to the islands) theoretically and focuses on how the internal areas (considered marginal for a long time) have considerable material and immaterial resources to be valorised. Second, the study evaluates the internal relationship networks that characterise the island territory through the cluster and principal components analysis using origin-destination data to represent vocations and population needs. A smart governance strategy is proposed for Sardinia through an assessment of the functionality of urban settlements and interconnections between the hinterlands (the small and the main cities of the case study), following the smart region paradigm. The study underlines the importance of the interconnection between urban geographical areas. Thus, given an analytical-numerical approach, the originality of this research is highlighted in how it is possible to extract social vocations of the territory, which is generally not easily quantifiable.
\end{abstract}

Keywords: smart governance strategy; smart island; smart region; mobility; origin-destination analysis; Sardinia

\section{Introduction}

Literature review [1-4] underlines how the economic, social and territorial cohesion is one of the main objectives of the Treaty on the Functioning of the European Union (TFEU, art. 174). However, the place-based cohesion in the island territories have more structural problems that make it more problematic to identify, understand and manage the entire territory through a smart government. Therefore, this article wants to understand how the analysis of dependencies between municipalities, allows adopting a smart governance differentiated according to the polarization characteristics of each area. To do this the authors start from the literature review and from analysis of urban polarities through the theory of central places (CPT), subsequently this is applied through a methodology that combines the economic, social and territorial aspects of the case study of Sardinia island (Italy).

About that, the TFUE aims to reduce the gap between regions, focusing above all on rural areas affected by industrial transition or those that present serious and permanent natural or demographic disadvantages, such as the northernmost regions with very low population density and the island regions [5,6]. Moreover, the European programme 2014/2020 [7] establishes an intervention strategy that can be summarised in three objectives: "(1) Protecting the territory and the safety of the 
inhabitants [ ... ] ; (2) Promoting natural and cultural diversity and polycentrism through an economic and social model that is able to create models of life in the internal areas that are competitive with urban areas both in the same region and outside the region [ . . ] ] and (3) Relaunching development and work through the use of potential misused resources" [7]. Hence, in Italy, the Economic and Social Cohesion Department within the EU Framework Programme Horizon 2020 highlights that $60 \%$ of the national territory in Italy consists of inland areas in which about a quarter of the Italian population lives [8,9]. In Italy, in 2012, the regional policy planning "methods and objectives for effective use of EU funds 2014-2020" defines the inland areas as unstable agglomeration centres with strong demographic issues. However, at the same time, they are strongly polycentric; they have the potential for attraction and resources that are lacking in the central areas [7]. In this context, the Technical Committee of the "Inner Areas" and the representatives of the various Italian Regions drafted the document relating to the National Strategy of Internal Areas to adapt primary services to the needs of the population and develop the local economy through local production chains [10]. This document has, therefore, initiated a new and widespread awareness in Italy regarding the internal areas to develop a complete framework and better plan for them by considering multipolar interconnections.

Thus, in Italy, the National Strategy of Internal Areas (2012) developed the concept of inland areas, which are linked to regional developments and interrelations with the main cities, by employing a planning process that is applied to local economic and sustainable developments [11]. In this concept, regional peculiarities must relate to large-scale strategic planning and the internal and main areas.

In July 2018, the Italian office for the evaluation of the Impact of Cohesion Policies in Europe [12] showed that, in line with the rest of Europe, despite the fact that the Italian structural funds had a significant effect on the GDP per capita [11], the place-based impact has negative results for individual Italian regions. Thus, the South of Italy, including the major islands (Sicily and Sardinia), "with its twenty million inhabitants, remains the largest less-developed area" ([12], pp. 10-11).

This concept becomes even more significant when it is applied to insular contexts. In fact, they have different structural disadvantages that not only create difficulties for economic and social development $[13,14]$ but also have their own place-based, physical, and managerial characteristics [15-20].

Starting from these assumptions and considering a regional data set to develop new ideas on regional planning [21,22], this study primarily determines a smart territory approach to analyse the phenomenon of the connection between inland and coastal areas by considering a particularly sensitive context, such as the island of Sardinia.

Sardinia appears to be particularly emblematic as a case study not only because it is an island context but also because, within the European programming 2014-2020 ([6], pp. 34-35), it belongs (together with Abruzzo and Molise) to the Italian regions with great difficulty in economic and social development. Moreover, the Sardinia region participates in the National Strategy for Italian Internal Areas (NSIA, from Italian: Strategia Nazionale per le Aree Interne Italiana-SNAI), where the peculiarities of the territory are seen as a fundamental potential to counteract the phenomenon of depopulation and promote economic and social development [23-25].

Thus, the study begins with an in-depth bibliographic and legislative analysis on the common problems of islands with their implications on the condition of insularity. In support of these reflections, the authors reflect on theories of central places (CPT) applied to mobility as a possible concrete application to island territories.

Subsequently, given the latest available data on mobility regarding origin-destination, after normalisation and rendering them as indicators, the study arrived at a methodology of territorial analysis, in which a cluster and a principal component analysis (PCA) are presented. Then, the articulation of homogeneous areas on which it is necessary to intervene is analysed. That is, the elaborated methodology recognises the dominant attractors of the largest urban areas within an insular system, and it can create and reorganise intermediate aggregations classified as "homogeneous areas" to provide a set of minimum services in weak internal environments, which is today not satisfied. 
Finally, the results of the study are presented and discussed by showing how the methodology adopted for the Sardinia region in different homogeneous areas consents to adopting differentiated policies according to the polarisation characteristics of each area.

\section{Literature Review on Common Issues Related to Insular Regions}

From a theoretical point of view, with the Treaty of Maastricht [26] in 1992, the European Union recognises the islands as ultra-peripheral regions. However, only in 1997, the "Declaration concerning the island regions" annexed to the Treaty of Amsterdam (1997) recognises, for the first time, the various structural disadvantages that hinder economic and social development, which are typical issues of island regions ([14], p. 136). Subsequently, EU legislation has increasingly recognised the presence of handicaps that lead to development shortages [27]; it introduced more specific financial and research actions to solve, at least in part, the common island problems (Table 1).

However, the European Union has primarily shown attention to the island problems in a theoretical way. Very little specific measures were produced "even though at the same time the islands have made good use of the instruments devoted to the policy of economic and social cohesion" ([27], p. 3). This situation may be partly due to the difficulty in finding a common classification for islands that serves as a starting point for place-based governance. Monfort, for example, argues [28] that in every island characterised by its own insularity and by political and socio-economic specificities, "the development is generally affected by a complex set of constraints, which are often not all specific to the type of territory included in that category. [ ... ] The main implication of such observations is that the categories of these specific territories are far from constituting homogenous groups of regions" ([28], p. 10).

The ESPON 2013 programme [29] instead underlines the intrinsic and extrinsic diversity of the island regions regarding others, thereby supporting the need to diversify the island policies "from $\mathrm{EU}$ and national goals for sustainable development, as well as those for economic, social and spatial cohesion. [ ... ] Thus, it becomes imperative to apply appropriate policies, which can enhance the islands' attractiveness" ([29], p. 14). The literature also shows a discrepancy not only in the classification but also on the number of islands present in Europe [30,31].

Furthermore, if the instruments for economic and social cohesion and the trans-European networks are the main tools used by the European Union to reduce the island's disadvantages [25], the proceedings of the 39th annual general meeting of the CPMR Island Commission of 2019 [32] show the legislative failures in matters of island development. However, in the 2016 Treaty on the Functioning of the European Union, articles 174 and 175 pay much attention to insular problems; thus, Member States conducted their economic policy to reduce the gap between the levels of development of the various regions and the delay of the less favoured regions including the island regions [5] (art. 174-175). In addition, the CPMR's Islands Commission (IC) notes, not only are "the existing regulatory framework and existing devices and measures insufficient" ([33], p. 4) but also there is a need for an effective solution to all the problems affecting the European island territories listed on the European Union in the Opinion of the Economic and Social Committee in 2000. Table 2 shows the structural problems and permanent disadvantages common to island regions [16,34], highlighting a series of structural indications for evaluating policies to be implemented in the governance of islands.

Italy has not yet defined its own legislation on insularity issues. In 2016, with decree 497, the Senate developed a framework law for the development of the smaller islands and Sicily and Sardinia have adopted the "condition of insularity".

This legislative revision shows the lack of a smart governance framework without giving general guidelines for island regions, as well as place-based strategies or policies able to solve problems of these territories with their daily habits. Namely, literature shows only specific case studies, by using, for instance, a minor island as a case study, or by giving the general characteristics of what a smart Island should be $[35,36]$, or trying to define what a smart island is $[16,17,37]$, or by applying the concept of smart governance in limited portions of territory [38,39]. Other studies associate the smart governance of an island with the use and impact of new information and communication technologies 
(ICT) [40], the effects of e-government development on environmental sustainability [41-43], or on urban sustainability [44].

Table 1. Summary of the major European initiatives on smart islands.

\begin{tabular}{|c|c|}
\hline Years & European Initiatives on Smart Islands \\
\hline $1992^{1}$ & Treaty of Maastricht, art. $129 \mathrm{~b}$ and "Declaration on the outermost regions of the Community". \\
\hline $1993^{2}$ & $\begin{array}{l}\text { ISLENET is the first network of island authorities promoting sustainable energy and } \\
\text { environmental management. }\end{array}$ \\
\hline $1997^{3}$ & Treaty of Amsterdam, art. 158CE (ex $130 \mathrm{~A})$ and "Declaration on island regions". \\
\hline 2000 & $\begin{array}{l}\text { Guidelines for integrated actions on the island regions of the European Union (EU Official Journal C } \\
268,19 \text { September 2000). }\end{array}$ \\
\hline $2002^{2}$ & $\begin{array}{l}\text { The Committee of the Regions presents the problems of island regions in the European Union, } \\
\text { emphasising the EU policies and regulation in the relevant areas. }\end{array}$ \\
\hline $2003^{4}$ & $\begin{array}{l}\text { Analysis of the island regions and outermost regions of the European Union. Part I: The island regions } \\
\text { and territories. }\end{array}$ \\
\hline $2007^{2}$ & $\begin{array}{l}\text { The European Parliament adopts the Motion for Resolution tabled by MEP Francesco Musotto, } \\
\text { which proposes tailored measures to some challenges facing European islands. }\end{array}$ \\
\hline $2009^{5}$ & $\begin{array}{l}\text { Territories with specific geographical features. A series of short papers on regional research and } \\
\text { indicators produced by the Directorate-General for Regional Policy. }\end{array}$ \\
\hline $2011^{2}$ & $\begin{array}{l}\text { The European Parliament officially recognises the Pact of Islands as an EU initiative that runs parallel } \\
\text { to the Covenant of Mayors. }\end{array}$ \\
\hline $2012^{2}$ & $\begin{array}{l}\text { EURELECTRIC publishes a report demonstrating islands' potential to become test-beds for } \\
\text { cutting-edge sustainable energy technologies. }\end{array}$ \\
\hline $2013^{2}$ & $\begin{array}{l}\text { Thirteen islands partners across Europe work together in clusters to mature sustainable energy projects } \\
\text { through enhanced multi-level governance. The key deliverable of SMILEGOV is the Smart } \\
\text { Islands Strategy. }\end{array}$ \\
\hline $2013^{6}$ & $\begin{array}{l}\text { The ESPON } 2013 \text { Programme. The Development of the Islands-European Islands and Cohesion } \\
\text { Policy (EUROISLANDS). }\end{array}$ \\
\hline $2014^{2}$ & $\begin{array}{l}\text { The Opinion calls for the implementation of smart policies and smart development initiatives at EU, } \\
\text { national, and regional levels that cater to the specific characteristics of islands. }\end{array}$ \\
\hline $2015^{2}$ & $\begin{array}{l}\text { The 35th Annual Conference of the CPMR Islands Commission marks a strong comeback of islands in } \\
\text { the European Parliament. Forty-one new members join the Pact of Islands, which today counts } \\
117 \text { members. }\end{array}$ \\
\hline $2015^{2}$ & $\begin{array}{l}\text { The European Parliament adopts the Resolution on the special situation of islands calling for an } \\
\text { Agenda for EU Islands accompanied by an EU Strategic Framework for Islands to link up financial } \\
\text { instruments that can have a major territorial impact. }\end{array}$ \\
\hline $2016^{2}$ & In Athens, on 21-22 June, DAFNI hosts the first Smart Islands Forum \\
\hline $2017^{2}$ & $\begin{array}{l}\text { On } 20 \text { February, EURELECTRIC publishes the "Towards the Energy Transition on Europe's Islands" } \\
\text { report, which highlights the role of islands in Europe's energy transition. }\end{array}$ \\
\hline $2017^{2}$ & $\begin{array}{l}\text { On } 28 \text { March, the islands make a strong comeback at the European Parliament to present the Smart } \\
\text { Islands Initiative and communicate their potential to transform into smart, inclusive, and thriving } \\
\text { societies for an innovative and sustainable Europe. }\end{array}$ \\
\hline \multicolumn{2}{|r|}{$\begin{array}{l}{ }^{1} \text { Treaty on European Union. Official Journal of the European Communities No C 191/3. https://eur-lex.europa.eu/ } \\
\text { legal-content/IT/TXT/?uri=CELEX:11992M/TXT (accessed on } 13 \text { July 2019). }{ }^{2} \text { Smart Island Initiative. The initiative: } \\
\text { the story behind. http://www.smartislandsinitiative.eu/en/history.php (accessed on } 13 \text { July 2019). }{ }^{3} \text { Treaty of } \\
\text { Amsterdam. http://www.europarl.europa.eu/topics/treaty/pdf/amst-en.pdf (accessed on } 13 \text { July 2019). }{ }^{4} \text { Analysis } \\
\text { of the island regions and outermost regions of the European Union https://ec.europa.eu/regional_policy/sources/ } \\
\text { docgener/studies/pdf/ilesrup/islands_part1_summary_en.pdf(accessed on } 13 \text { July 2019). }{ }^{5} \text { Monfort,P. Territories with } \\
\text { specific geographical features. https://ec.europa.eu/regional_policy/sources/docgener/work/2009_02_geographical. } \\
\text { pdf (accessed on } 13 \text { July 2019). }{ }^{6} \text { The ESPON } 2013 \text { Programme The Development of the Islands_European Islands } \\
\text { and Cohesion Policy (EUROISLANDS). https://www.espon.eu/sites/default/files/attachments/inception_report_full_- } \\
\text { version.pdf (accessed on 13 July 2019). }\end{array}$} \\
\hline
\end{tabular}


Table 2. Structural problems common to island regions derived from the Opinion of the Economic and Social Committee (Official Journal of the European Union C 268, 19 September 2000).

\begin{tabular}{cl}
\hline \multicolumn{1}{c}{ Permanent Disadvantages and Common Characteristics of Islands Contexts } \\
\hline 1 & Isolation from land \\
\hline 2 & $\begin{array}{l}\text { Higher cost of maritime and air transport, communications and infrastructure due to natural and } \\
\text { climatic obstacles }\end{array}$ \\
\hline 3 & Limited extension of usable land \\
\hline 4 & Poor fishing resources \\
\hline 5 & Limited water resources \\
\hline 6 & Limited energy sources \\
\hline 7 & Marine and coastal pollution \\
\hline 8 & Particular difficulty in waste management \\
\hline 9 & Population decline, particularly of young people \\
\hline 10 & Coastal erosion \\
\hline 11 & Lack of qualified personnel \\
\hline 12 & Absence of an economic environment favourable to entrepreneurship \\
\hline 13 & Difficult access to school and health services \\
\hline
\end{tabular}

For these reasons, this paper aims to show how the study of mobility, through the analysis of origin-destination shifts $(\mathrm{O} / \mathrm{D})$, can describe the vocations and needs that characterize the territory through the network of relations and attitudes of citizens.

However, a general governance framework for major islands is still lacking. In fact, these kind of islands by their nature have a net distinction between inland areas and coastal ones, as well as a replicable methodology that can allow not only a complete study of the island territory, starting from the usual habits and actions of population, but also a smart governance able to solve the structural and common problems of many European Islands.

Before describing this, the authors consider it necessary to highlight, in the next section, that one of the major problems of insularity is the clear difference in planning between inland areas and coastal cities [45,46]; thus, in most cases, the settlements that are on the coastal areas are the main centres of the whole island [47]. This phenomenon, which the authors explain through the spatial distribution linked to the theory of central places (CPT), has important consequences on the interrelations between major cities and inland areas.

\section{The Analysis of Urban Polarities to Understand the Interconnection between Inner End Coastal Areas in Insular Regions}

The problem with inland areas is particularly evident in the literature on an island context $[45,48,49]$, especially when (as in Sicily and Sardinia for Italy) larger islands are considered for their development, comparable with non-island regions. Therefore, it was necessary to find a solution to the problem of managing these areas through a common policy that concerns the whole Region. This section explained, through central theories, how the multipolar interconnection can provide a common smart governance to different urban poles within an insular system.

Moreover, "the identification of the internal areas [... ] starts from a polycentric interpretation of the territory [ ... ] characterised by a network of municipalities or groups of municipalities [ ... ] around which gravitate areas characterised by different levels of the spatial periphery" ([50], p. 1). This situation makes it necessary to support this study with the main models of representation of the regional structure as the planning of multipolar interconnections. In fact, the theme of island development, especially in terms of smart planning in a regional geographical area, reflects on the 
theory of central places (CPT) through a synthesis of the organisation mechanisms between major cities, suburbs, inland areas and rural areas [51,52]. The first theories on CPT [53-55] studied the territorial rebalancing through multi-level urban hierarchies that established places of great economic and social development [53]. In the course of its evolution, the concept of central places was applied by different urban planning models, mainly based on the regional economy [56-58]. Christaller (1933) and Lösch (1941), pioneers of the concept of central place system [53-56] interpret central locations as hierarchical centres at multiple levels that establish the main places on the economic and social level [54]. These models also allow for evaluating the principles that determine the number, size, and distribution of cities $[6,54,59]$, thus, including relationships between the city centre and internal areas and the effects they produce.

Although they are old models since they were applied in different periods and contexts from those of today, they can still be valid in an insular system in their theoretical formulation, adopting more current tools and methodologies. This situation is because the characteristics of the geographical and spatial structure of an island have, by their nature, a precise boundary (the system of an island is closed and isolated) that allows the analysis of the urban system within it, stressing the concept of main and secondary hubs. Moreover, if, over the years, the literature changed the forms of use of central place theory [60-66] and their application to specific contexts [67-71], the concept of central localization is still applied to urban planning, correlating the spatial distribution of settlements with, for example, public structures [72-74], industries [75,76], and the tourism sector [77-82]. Furthermore, the study correlated the optimal localisation strategy with the economic demand of defined geographical areas. Thus, Van Meeteren and Poorthuis [68] propose the study of settlement geographies through the analysis of social media by adopting as the basis of research the theory of central places to demonstrate how, today, through the data collected by computer analysis, it is possible to shape the geographical economic-urban areas [68]. The model was also applied to insular contexts, mainly using an economic approach to enhance the area through the location of the main tourist polarities [83-86].

In regional planning, these models are integrated with the analysis of mobility flows [87-90] as a fundamental component to understanding the movements and the population needs. Lenormand and Ramasco [91] argue on how technology can help regarding the analysis of urban systems and human mobility to better understand urban dynamics. Mulíček and Malý [89] argue that changes in commuting workflows show the development of the urban system hierarchy. Similarly, Mitchell [90] notes that the settlements are organised in networks of shifts, identifiable around the major hub. In fact, the importance of a representation of the dynamics of population displacement in urban hubs at different levels allows for understanding not only a local classification of the centres but also the effects that strong hubs can produce in the weaker urban centres with the aim of a regional and place-based rebalancing [92].

The analysis of the urban polarities of an island acquires even more value if analysed from the point of view of mobility as the impossibility of expanding beyond island boundaries makes the analysis of population flows effective in understanding the main hubs. This situation creates the opportunity to evaluate the functionality of urban settlements and their interconnections within the system and, therefore, reflects a smart governance strategy [93] capable of modifying normal flows through the analysis of the needs and of the vocations of the same population.

In this regard, the study uses a methodology applied to the insular context of Sardinia in Italy, to redefine urban strategic polarities using the theory of central places (CPT) applied to the mobility sector through the principal component analysis and the cluster analysis. This methodology not only demonstrated the relevance and practicality of the CPT in the study of urban strategic polarities in the Islands context but allows for responding to the three problems indicated by the National Strategy of the Italian Areas, which are key points of the regional island development.

(1) The polycentric articulation of the territory describes Italy in two historical subsystems (large, medium, small urban systems; and internal areas). They had divergent economic development 
and industrial take-off, causing "the stagnation, degrowth and development of the Inner Areas" ([10], p.14).

(2) The internal areas have an unused territorial capital, where the economic decrease regards the social unease, linked to the lack of basic services and the social costs generated by the production and consumption processes ([10], pp. 14-15).

(3) The demographic decline in the population, with a strong decrease in births and an increase in the elderly population, remains a strategic objective to intervene to develop inland areas, reversing today's demographic trend ([10], p. 20).

However, before going into detail and describing the methodology, the authors present the case study of Sardinia, an island in the middle of the Mediterranean.

\section{The Case Study of the Island of Sardinia in Italy}

Sardinia is the largest island in Italy after Sicily (Figure 1). It covers 24,100.02 square kilometres and has a population of 1,639,591 inhabitants [94] with a density of 68 inhabitants per sq km, unlike Sicily which extends for 25,832.39 square kilometres with a density of 194 inhabitants per sq km [95]. Sardinia has 377 municipalities [95], which is distributed according to the five administrative territorial divisions [96]: 17 to the metropolitan city of Cagliari; 74 to the province of Nuoro; 87 to the province of Oristano; 92 to the province of Sassari; and 107 to the province of Southern Sardinia [97].

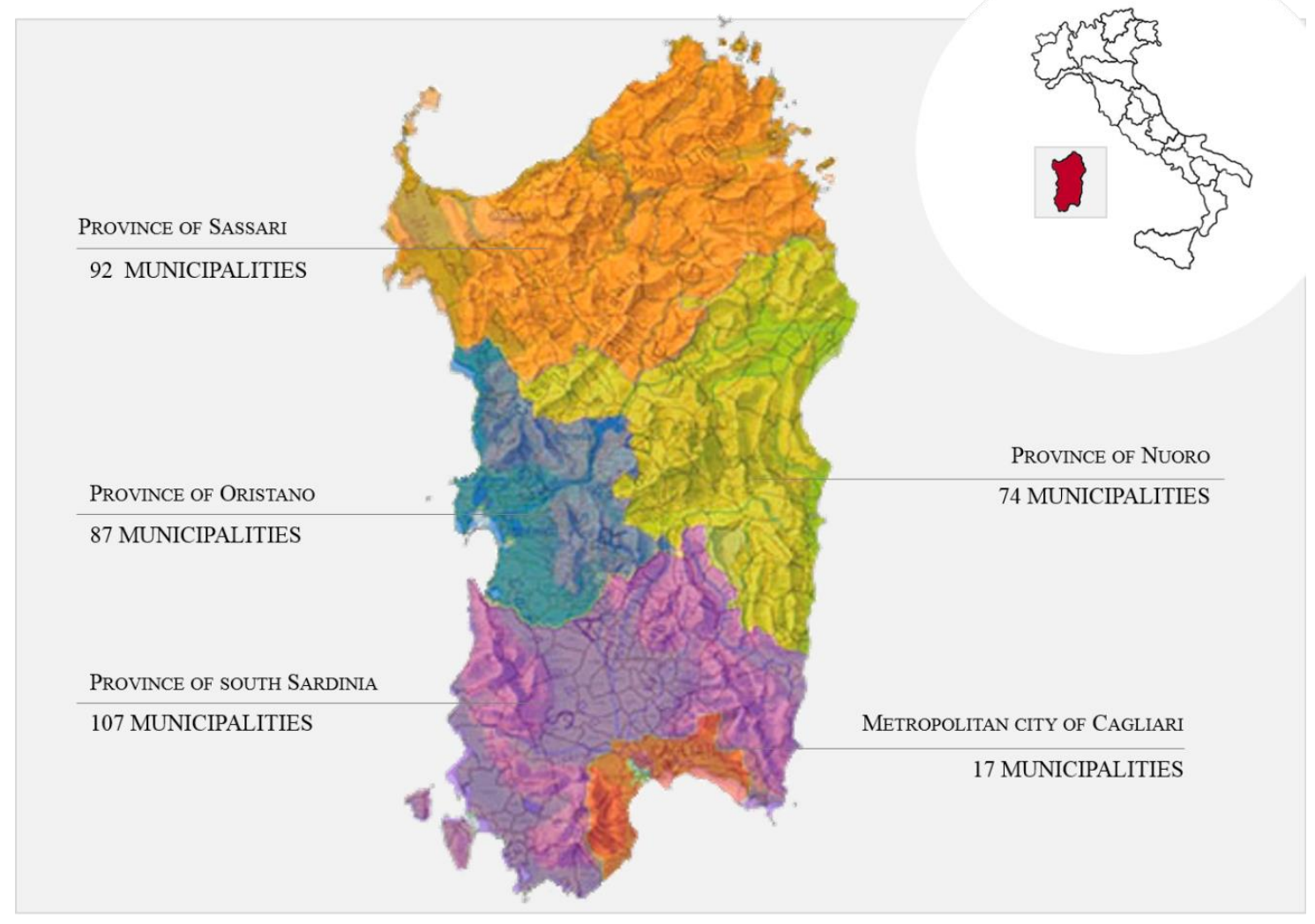

Figure 1. Sardinia island with its morphology and its five administrative territorial divisions.

The morphological and geographical characteristics, which are very different between coastal landscapes and the hinterland, have, over time, created different degrees of polarity. The coastal areas, which are an unquestionable heritage for the island, are the main polarities as they constitute the greatest potential for tourism and economic development. The Sardinian hinterland is less known by mass tourism than the coastal landscapes. Here, the economy suffers due to lack of work 
and services, as well as the depopulation of municipalities, thus, becoming secondary polarities that need connections with the coastal area to survive. In these areas, the weakness of the general system leads to considering the need to redesign the levels of attraction by acting on the reduction of circulation impedances and medium-sized services (hospitals, school facilities, and shopping centres). Furthermore, potential polarities can be distinguished by considering those that, due to their proximity to coastal areas and average infrastructure connections, can maintain an economy and good social development.

Therefore, the case study of Sardinia is emblematic for several reasons. The economic development and the social and demographic context of the island show "some signs of fragility: the low birth rate, combined with the low incoming mobility, determines a spiral of natural decrease in the population [ ... ] and the ageing process of the population" [98]. In addition to the demographic and economic decline, the Sardinian territorial system is particularly interesting as a closed system that allows an unambiguous and stable reading of the flows. It is important to study the origin-destination shifts to understand how the population moves within the island. Thus, supported by the aforementioned theoretical models, the needs of the population are first identified, and then the main centres of the island are identified.

Therefore, given the premises of the European Community and of the National Internal Technical Committee concerning the problems of economic, social, and territorial cohesion and the issues highlighted by the analysis of central place theory and structural problems typical of the region's insular context, an analysis of the origin-destination $(\mathrm{O} / \mathrm{D})$ shifts is proposed to describe the vocations and needs that characterise the territory through the network of relationships and attitudes of citizens.

\section{Methods}

Sardinia, given the related problems common to the islands previously described, finds a better declination in the analysis of urban polarities through the theory of central places. The CPT allows for reflecting on which connection mechanisms are useful in a closed system where the coastal area is different (in terms of economy, morphology and demography) from the internal area. The main goal is to understand the strongest urban polarities of the island system through the interactions between geographical areas analysed through the analysis of mobility data.

The analysis of mobility data allows for describing the network of relationships and attitudes of the citizens through the analysis of the origin-destination $(\mathrm{O} / \mathrm{D})$ shifts. They represent the result of the vocations and needs that characterise a subsystem of the entire territory. Vocations such as identity, demographic structure, history, culture, and the needs of the citizens regarding education, work, health, services, and entertainment are bound by the physical characteristics, such as the transport networks, orography, climate. The movements of citizens express their vocations and needs, and they emerge in the statistical data recorded in the O/D matrices. The analysis of the spatial distribution of the matrices can, therefore, highlight structures and dependencies between different parts of the territory.

The data on which the analysis is based is the recurrent daily trips of entering and leaving each municipality divided by the destination municipality. Additional information is the average travel time, the means used, and the reason for moving (study or work).

The data do not, therefore, represent the universe of mobility because an important percentage of movements is subtracted from monitoring. Repetitive trips can take place for other reasons (such as health needs, leisure, shopping, tourism) in destinations and modes. Several studies used PCA and CA analysis for land-use and urban plan [99-103]. These techniques have been frequently used to study socio-economic parameters including social, environmental, and urban evolution and as a numerical base for land-use and urban planning. However, they have strengths and weaknesses: the strong point is the robust mathematical objective method and their weakness is the same mathematical objective method. In fact, it fails to fully consider many social aspects of planning that cannot be quantified. 
While it is difficult to define the part related to tourism and leisure, this rate, estimated at around $30 \%$ of the total, can be, in part, related to the previous one as far as the territorial distribution is concerned.

From a methodological point of view, the authors conducted an analysis in main components and later, a cluster analysis of the origin-destination (O/D) mobility data surveyed by ISTAT (Italian Institute of Statistics) of 2015 (the latest data available).

The study illustrates a series of statistical calculations and territorial contouring, where different significant indexes of the characteristics of mobility and functional dependencies between the different municipalities are mapped.

An important consideration for the analysis developed in the study consists of observing how the depopulation phenomena involve the mountain areas to a greater extent than the coastal and flat areas. The abandonment of mountain areas is a well-known phenomenon and is well correlated with the altitude of the centre considered. Firstly, cluster analysis is conducted to group statistical units by minimising the "logical distance" within each group and maximising the external one between groups [104]. The "logical distance" is evaluated by parameters of similarity-dissimilarity between the statistical units.

The k-means function allows to aggregate data into k mutually exclusive clusters and returns the clustering index for each data. Each cluster is defined by its objects and by its centroid, the point to which the sum of distances from all objects is minimised. The "distance" can be evaluated differently in the O/D data analysis algorithm for cluster centre initialisation and the squared Euclidean metric to determine distances (Figure 2).

The cluster analysis (CA) allows for identifying a minimum number of groups such that the elements belonging to a group are, in some sense, more similar to each other than the elements of other groups. In summary, it is possible to search for groups of objects such that the elements that belong to them are "similar" to each other and different from those of other groups.

The principal component analysis (PCA) identifies the underlying structure of the observed relationships. A limited number of new variables, called main components, resulting from the linear combination of the starting variables, allow for a convenient description of the system, eliminating redundancies in the data $[105,106]$.

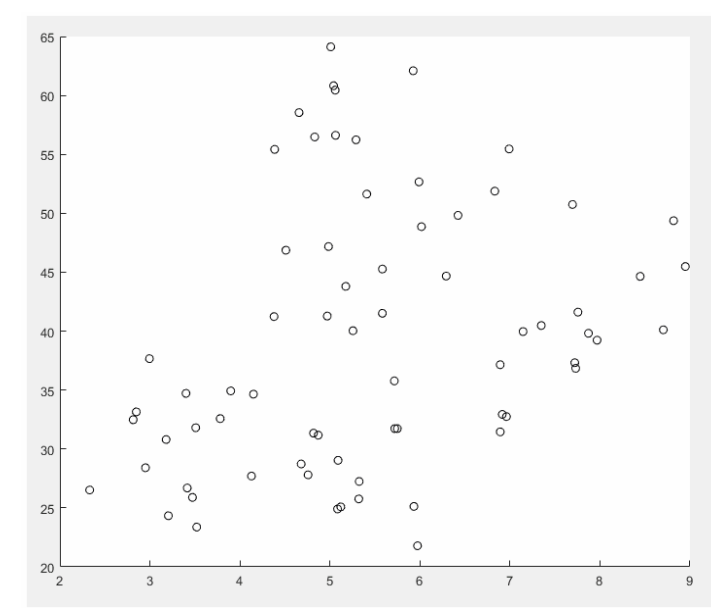

(a)

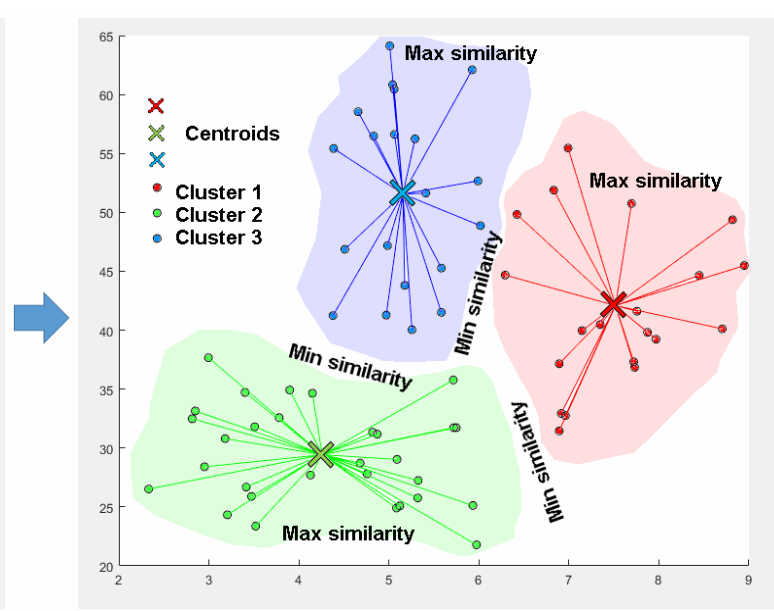

(b)

Figure 2. Evaluation of the "logical distance" in cluster analysis: (a) distribution of units; (b) example of grouping statistical units by minimising the "logical distance" within each group.

In the multivariate analysis, it is difficult to visualise data when there are more than five parameters. Thus, using colours and marker size, it is possible to describe the fourth and fifth variables in the xyz Cartesian system. Thus, when many variables are involved in the investigation, their relationships 
cannot be extracted by analysing the graphs. Fortunately, it is very often observed that groups of variables move together because of the same driving force governing their behaviour. In this case, it is possible to simplify the problem by replacing a group of parameters with a single new variable.

As an example, Figure 3 shows how the general behaviour of the winds can be approximated by the five vectors on the right rather than by the thousands of single values on the left.

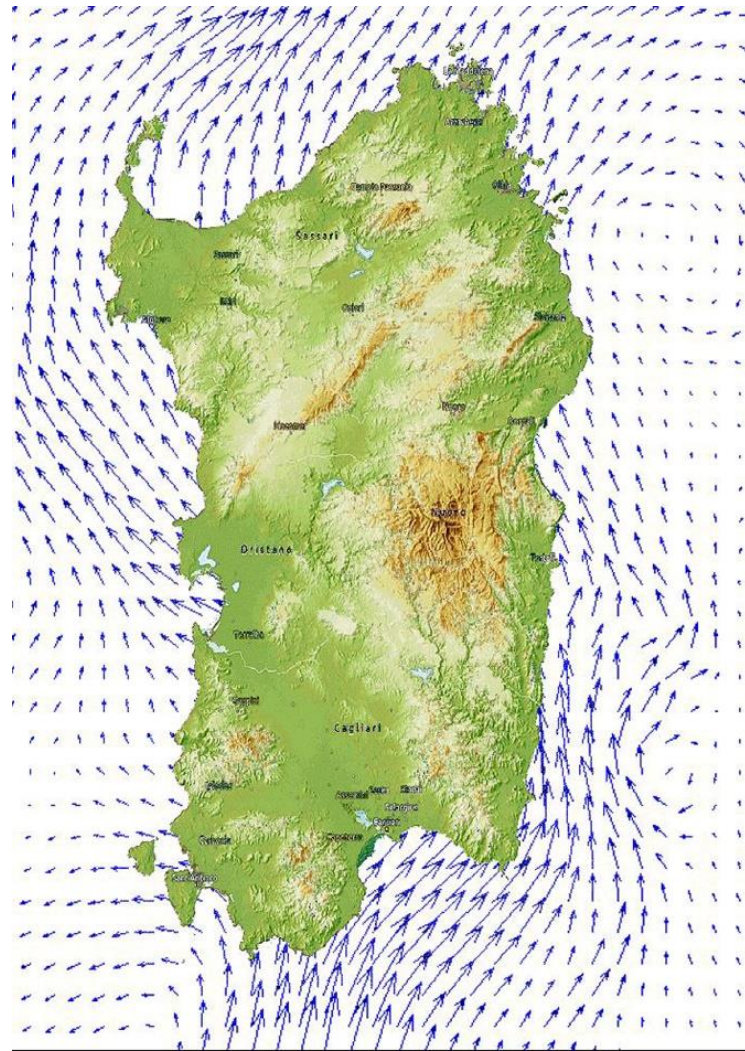

(a)

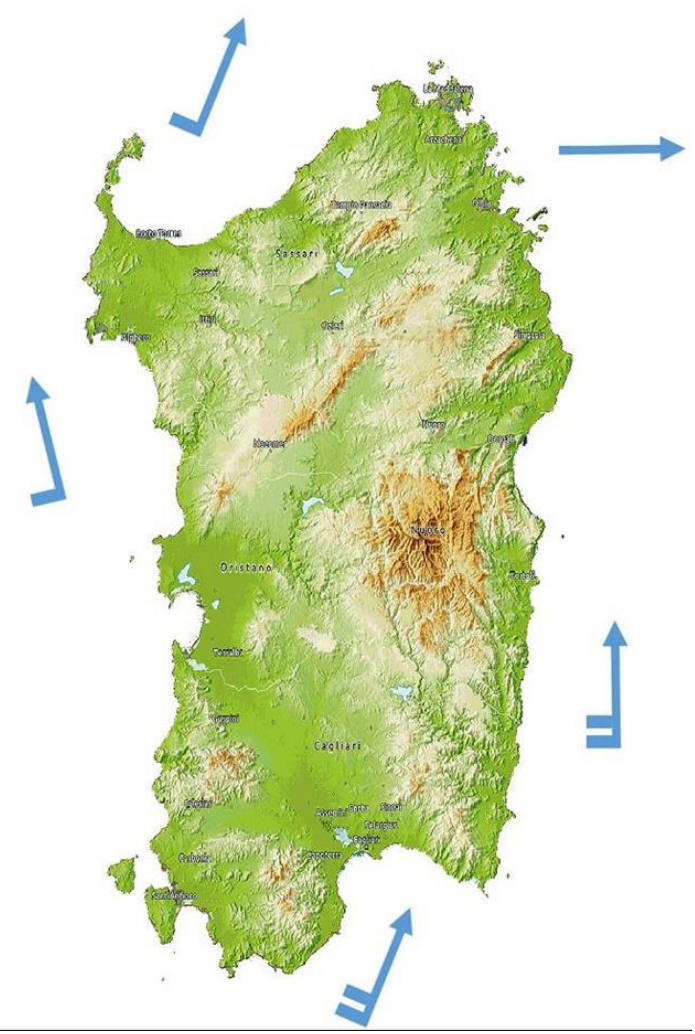

(b)

Figure 3. Example of the principal component analysis (PCA): (a) general behaviour of the winds by the thousands of single values; (b) general behaviour of the winds approximated by the five vectors.

The PCA is a quantitatively rigorous technique for this simplification, substituting old variables in a new set of parameters called principal components (PA). Each PA is a linear combination of the old variables.

Among an infinite number of combinations, the first PA has the maximum variance of old variables, and it is described as a single axis in space. The second PA is another axis in space, orthogonal to the first. The new combination has the maximum variance on this second axis.

It is possible to iterate the procedure until the same number of initial variables explains $100 \%$ of the original variance. However, a few PAs can explain more than $80-90 \%$ of the original variance.

Thus, there is clarity on how the outgoing movements from each municipality can be mainly traced back to the presence of dominant attractors: the main urban areas.

The combination of the theory of central places (CPT), CA, and PCA, which is applied to the $\mathrm{O} / \mathrm{D}$ matrix, represents the original contribution of the study, as the literature does not report similar examples.

Finally, the physical characteristics of the transport networks are considered through the isochrones; namely, the time needed to reach any other point in the transport network from a centroid. For this analysis, a network graph is used where each node (n) represents a point of intersection of the branches of the transport network, and the arcs (a) represents the physical connection between them. Each node 
is characterised by its geographical coordinates and by the time required for its crossing. The arcs are defined not only by the nodes that also connect to the travelling speeds but also the flows that interest them. In this way, it is possible to determine the crossing time of each arc. On the graph so defined, the Dijkstra's algorithm is applied [107].

Dijkstra's algorithm is a procedure to find the shortest paths between nodes in a graph. The original algorithm has been applied to obtain the path between any two nodes and the total travel time, adding the time of each link. The process can be iterated to calculate the total time between one node (the source) and all other nodes of the graph. The algorithm explores the node starting from the source, considering the infinite time to reach other points. During the first iteration, the nodes connected to the source (border nodes) are considered by assigning the minimum value between infinity and the travel time of each link. At the first step, all nodes linked to the source have the correct total travel time. The source is marked as a visited node. In the second step, all border nodes are selected, and the previous procedure is repeated for each. At the end of the second step, the neighbouring border nodes have the correct total travel time. The border nodes are marked as visited nodes, and the neighbouring of border nodes became new border nodes.

Once the distribution of the time needed to reach all the other points of the network from a centroid is known, it is possible to evaluate the overall time and the average time of the centroid.

Finally, the trend line is investigated on the available population data; that is, its density and variation over time, the number of displacements, the average travel time from each centre, and altitude. This trend line explains the variance observed regarding maximum correlation $(R$ and $R 2)$ with depopulation.

The correlation expresses any statistical relationship between two variables (causal or not) and can be understood as their dependence or association. Correlations can be useful tools in predicting relationships or revealing hidden associations. Among different approaches, Pearson's correlation was applied, where $R$ is evaluated as:

$$
R=\frac{\sigma x y}{\sigma x \sigma y}=\frac{\sum_{i=1}^{n}\left(x_{i}-\mu_{y}\right)\left(y_{i}-\mu_{y}\right)}{\sqrt{\sum_{i=1}^{n}\left(x_{i}-\mu_{y}\right)^{2} \cdot \sqrt{\sum_{i=1}^{n}\left(x_{i}-\mu_{y}\right)^{2}}}}
$$

If the variables are independent, then $R=0$. For a perfect increasing linear dependence, $R$ assumes the maximum value of +1 , while $R=-1$ express the perfect opposite linear relationship dependence (anticorrelation).

Moreover, a coefficient of determination $(R 2)$ is evaluated to provide an estimation of how the data are well simulated by the model. There are several definitions of $R 2$. In the simple linear regression (when an intercept is included) $R 2$ is simply the square of the sample correlation coefficient $R$.

\section{Application to the Case Study of Sardinia}

The percentage of internal displacements in Sardinia is equal to $98.4 \%$ of the total. The island's daily mobility takes place predominantly as a closed system; movements are prevalently directed to and from areas of the same region. Considering the theory of central places that, starting from the concept of urban hierarchy, interpreted the size, frequency, and distance of urban centres, the territory of the island is analyzed to highlight its structure, subsystems, and related relationships. 
Therefore, for the cluster analysis, a Euclidean metric is used, and a hierarchical aggregative method is applied to 35 clusters compared to 377 initial objects (the 377 Sardinian municipal administrations). The O/D matrix $(377 \times 377)$ in which each row represents the number of shifts facing the remaining 376 municipalities and the municipality itself. The diagonal represents intra-municipal movements (exiting from $i$ and facing $i$ ). It is possible to interpret these shifts as the intensity of the relationships or attraction of $i$ towards other gravitational areas. The cluster analysis was conducted using the "Statistics and Machine Learning" Toolbox in the Matlab environment [108] with the k-means technique (Table 3).

Given the assessment of accessibility, Figure 4 shows how the network graph was outlined, starting from the geometric and velocity characteristics of each stretch of the transport networks. The application of Dijkstra's algorithm on the graph allows for determining the travel times.

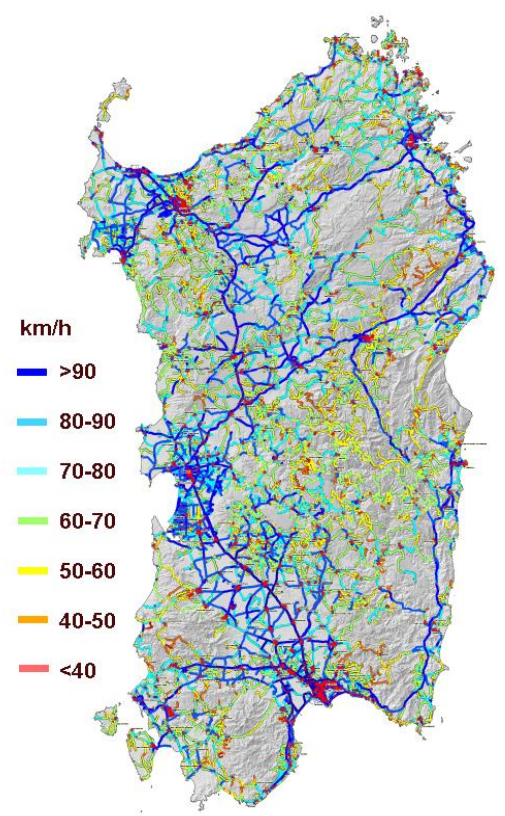

(a)

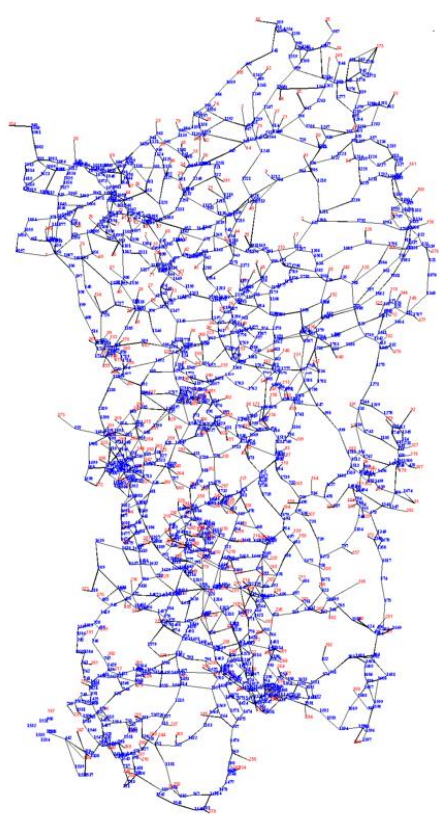

(b)

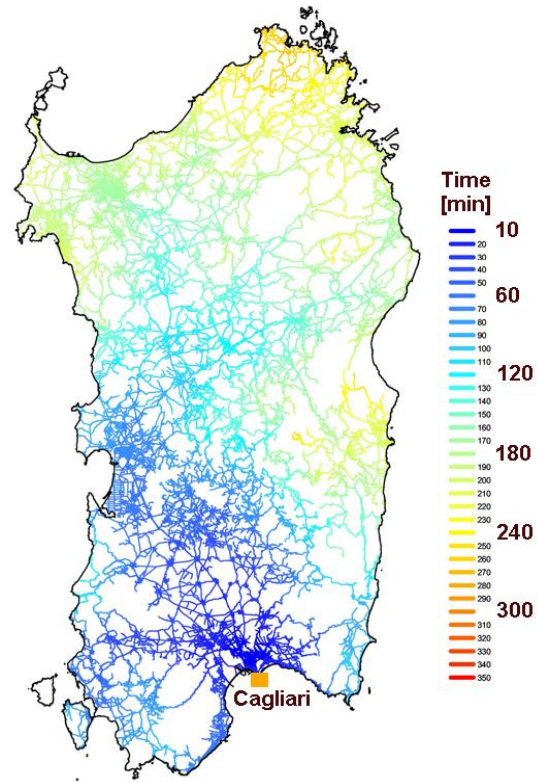

(c)

Figure 4. (a) The mean speed of road network; (b) the network graph; (c) the isochronous with the centre source of Cagliari.

Table 4 shows the multiplicity of data on which a systematic statistical analysis is performed, in order to identify the maximum correlations between the physical and functional characteristics of the transport network (isochrones, altitude, average times), displacement indices (generation and attraction, inter-municipal and intra-municipal ones) and population changes. 
Table 3. The daily matrix origin-destination (O/D) with the 377 municipalities of Sardinia.

\begin{tabular}{|c|c|c|c|c|c|c|c|c|c|c|c|c|c|c|c|c|c|c|c|c|c|c|c|c|c|c|}
\hline Municipalities & 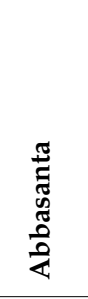 & 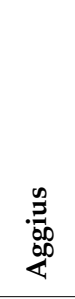 & 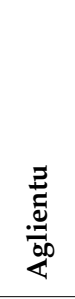 & 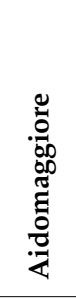 & 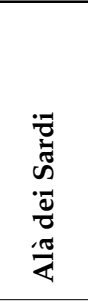 & 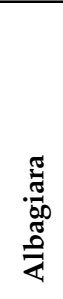 & $\stackrel{\infty}{\frac{\infty}{4}}$ & $\frac{O}{\frac{0}{2}}$ & 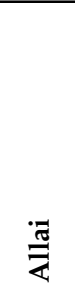 & $\frac{\pi}{\mathbb{\Xi}}$ & 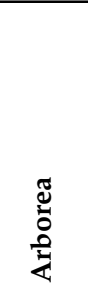 & $\frac{n}{2}$ & $\frac{\pi}{\overparen{\Xi}}$ & 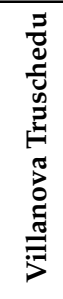 & 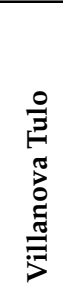 & 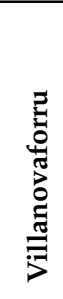 & 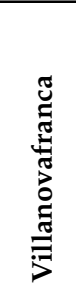 & 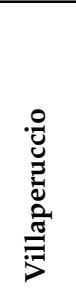 & 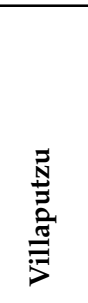 & 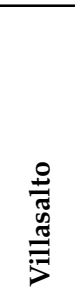 & 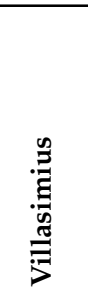 & $\underset{\stackrel{D}{0}}{\stackrel{0}{\equiv}}$ & 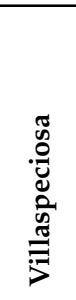 & 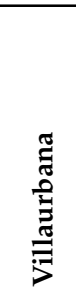 & 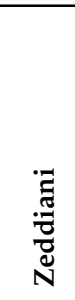 & 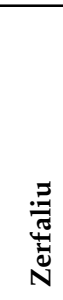 \\
\hline Abbasanta & 1190 & 0 & 0 & 6 & 0 & 0 & 0 & 0 & 0 & 0 & 4 & 0 & 0 & 0 & 0 & 0 & 0 & 0 & 0 & 0 & 0 & 0 & 0 & 2 & 0 & 2 \\
\hline Aggius & 0 & 780 & 12 & 0 & 0 & 0 & 0 & 2 & 0 & 0 & 0 & 0 & 0 & 0 & 0 & 0 & 0 & 0 & 0 & 0 & 0 & 0 & 0 & 0 & 0 & 0 \\
\hline Aglientu & 0 & 8 & 504 & 0 & 0 & 0 & 0 & 0 & 0 & 0 & 0 & 0 & 0 & 0 & 0 & 0 & 0 & 0 & 0 & 0 & 0 & 0 & 0 & 0 & 0 & 0 \\
\hline Aidomaggiore & 12 & 0 & 0 & 110 & 0 & 0 & 0 & 0 & 0 & 0 & 0 & 0 & 0 & 0 & 0 & 0 & 0 & 0 & 0 & 0 & 0 & 0 & 0 & 0 & 0 & 0 \\
\hline Alà dei Sardi & 0 & 0 & 0 & 0 & 1048 & 0 & 0 & 0 & 0 & 0 & 0 & 0 & 0 & 0 & 0 & 0 & 0 & 0 & 0 & 0 & 0 & 0 & 0 & 0 & 0 & 0 \\
\hline Albagiara & 0 & 0 & 0 & 0 & 0 & 44 & 10 & 0 & 0 & 0 & 0 & 0 & 0 & 0 & 0 & 0 & 0 & 0 & 0 & 0 & 0 & 0 & 0 & 2 & 2 & 0 \\
\hline Ales & 0 & 0 & 0 & 0 & 0 & 6 & 744 & 0 & 0 & 0 & 0 & 2 & 0 & 0 & 0 & 2 & 0 & 0 & 0 & 0 & 0 & 0 & 0 & 4 & 0 & 0 \\
\hline Alghero & 0 & 2 & 0 & 0 & 2 & 0 & 0 & 29,024 & 40 & 0 & 6 & 0 & 0 & 0 & 0 & 0 & 0 & 0 & 0 & 0 & 0 & 0 & 0 & 0 & 0 & 0 \\
\hline Allai & 2 & 0 & 0 & 0 & 0 & 0 & 0 & 0 & 166 & 0 & 0 & 0 & 0 & 0 & 0 & 0 & 0 & 0 & 0 & 0 & 0 & 0 & 0 & 2 & 0 & 0 \\
\hline Anela & 0 & 0 & 0 & 0 & 0 & 0 & 0 & 2 & 0 & 246 & 0 & 0 & 0 & 0 & 0 & 0 & 0 & 0 & 0 & 0 & 0 & 0 & 0 & 0 & 0 & 0 \\
\hline Arborea & 4 & 0 & 0 & 0 & 0 & 0 & 2 & 0 & 0 & 0 & 2878 & 6 & 0 & 0 & 0 & 0 & 0 & 0 & 0 & 0 & 0 & 2 & 0 & 2 & 0 & 0 \\
\hline Arbus & 0 & 0 & 0 & 0 & 0 & 0 & 0 & 0 & 0 & 0 & 6 & 2978 & 0 & 0 & 0 & 2 & 0 & 2 & 2 & 0 & 0 & 10 & 2 & 0 & 0 & 0 \\
\hline Ardara & 0 & 0 & 0 & 0 & 0 & 0 & 0 & 10 & 0 & 0 & 0 & 0 & 358 & 0 & 0 & 0 & 0 & 0 & 0 & 0 & 0 & 0 & 0 & 0 & 0 & 0 \\
\hline $\begin{array}{l}\text { Villanova } \\
\text { Truschedu }\end{array}$ & 6 & 0 & 0 & 0 & 0 & 0 & 0 & 0 & 4 & 0 & 0 & 0 & 0 & 64 & 0 & 0 & 0 & 0 & 0 & 0 & 0 & 0 & 0 & 0 & 0 & 0 \\
\hline Villanova Tulo & 0 & 0 & 0 & 0 & 0 & 0 & 0 & 0 & 0 & 0 & 2 & 0 & 0 & 0 & 612 & 0 & 0 & 0 & 0 & 0 & 0 & 0 & 0 & 0 & 0 & 0 \\
\hline Villanovaforru & 0 & 0 & 0 & 0 & 0 & 2 & 24 & 0 & 0 & 0 & 0 & 0 & 0 & 0 & 0 & 218 & 0 & 0 & 0 & 0 & 0 & 0 & 0 & 0 & 0 & 0 \\
\hline Villanovafranca & 0 & 0 & 0 & 0 & 0 & 0 & 2 & 0 & 0 & 0 & 0 & 0 & 0 & 0 & 0 & 4 & 564 & 0 & 0 & 0 & 0 & 4 & 0 & 0 & 0 & 0 \\
\hline Villaperuccio & 0 & 0 & 0 & 0 & 0 & 0 & 0 & 0 & 0 & 0 & 0 & 0 & 0 & 0 & 0 & 0 & 0 & 344 & 0 & 0 & 0 & 4 & 0 & 0 & 0 & 0 \\
\hline Villaputzu & 0 & 0 & 0 & 0 & 0 & 0 & 0 & 0 & 0 & 0 & 0 & 0 & 0 & 0 & 0 & 0 & 0 & 0 & 2496 & 4 & 62 & 0 & 0 & 0 & 0 & 0 \\
\hline Villasalto & 0 & 0 & 0 & 0 & 0 & 0 & 0 & 0 & 0 & 0 & 0 & 0 & 0 & 0 & 0 & 0 & 0 & 0 & 18 & 582 & 2 & 0 & 0 & 0 & 0 & 0 \\
\hline Villasimius & 0 & 0 & 0 & 0 & 0 & 0 & 0 & 0 & 0 & 0 & 0 & 0 & 0 & 0 & 0 & 0 & 0 & 0 & 14 & 0 & 2652 & 2 & 2 & 0 & 0 & 0 \\
\hline Villasor & 0 & 0 & 0 & 0 & 0 & 0 & 0 & 0 & 0 & 0 & 0 & 4 & 0 & 0 & 0 & 0 & 2 & 0 & 4 & 0 & 2 & 2926 & 14 & 0 & 0 & 0 \\
\hline Villaspeciosa & 0 & 0 & 0 & 0 & 0 & 0 & 0 & 0 & 0 & 0 & 2 & 0 & 0 & 0 & 0 & 0 & 0 & 0 & 0 & 0 & 0 & 30 & 870 & 0 & 0 & 0 \\
\hline Villaurbana & 0 & 0 & 0 & 0 & 0 & 0 & 6 & 0 & 4 & 0 & 12 & 0 & 0 & 0 & 0 & 0 & 0 & 0 & 0 & 0 & 0 & 0 & 0 & 626 & 0 & 0 \\
\hline Zeddiani & 8 & 0 & 0 & 0 & 0 & 0 & 0 & 0 & 0 & 0 & 0 & 0 & 0 & 0 & 0 & 0 & 0 & 0 & 0 & 0 & 0 & 0 & 0 & 0 & 354 & 0 \\
\hline Zerfaliu & 4 & 0 & 0 & 0 & 0 & 0 & 0 & 0 & 0 & 0 & 14 & 0 & 0 & 2 & 0 & 0 & 0 & 0 & 0 & 0 & 0 & 0 & 0 & 4 & 8 & 386 \\
\hline
\end{tabular}


Table 4. The set and organization of available data.

\begin{tabular}{|c|c|c|c|c|c|c|c|c|c|c|c|c|c|c|c|c|c|c|c|c|c|c|c|c|c|c|c|c|c|c|c|c|c|c|c|c|c|}
\hline 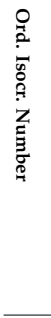 & ב⿳亠二口犬 & 罥 & $\begin{array}{l}z \\
z \\
z\end{array}$ & 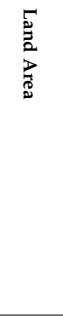 & $\begin{array}{l}0 \\
\frac{0}{\sigma} \\
\frac{0}{n}\end{array}$ & 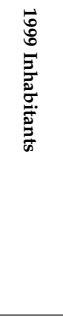 & 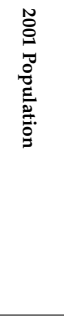 & 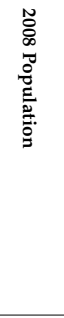 & 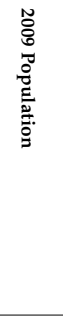 & $\underset{\mathrm{g}}{\stackrel{\mathrm{g}}{\mathrm{g}}}$ & 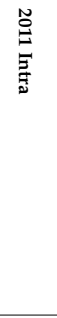 & 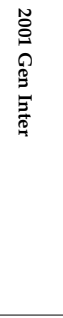 & 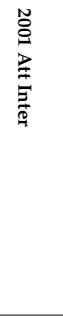 & 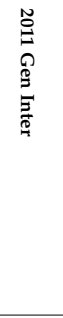 & 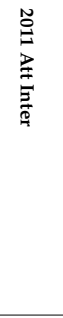 & 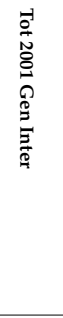 & 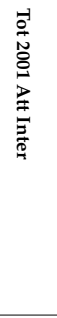 & 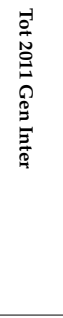 & 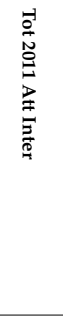 & 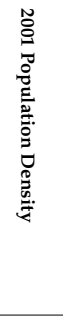 & 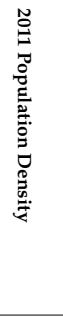 & 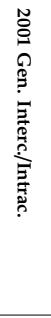 & 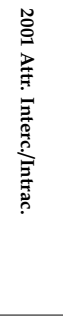 & 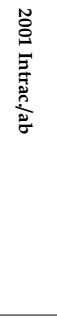 & 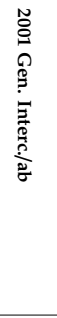 & 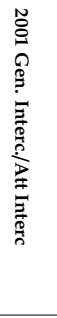 & 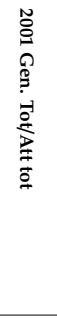 & 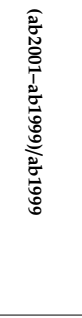 & 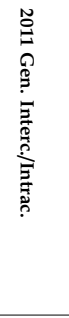 & 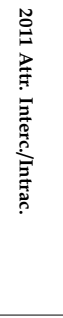 & 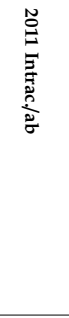 & 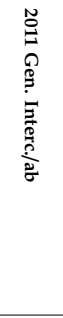 & 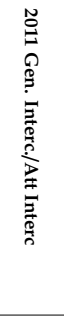 & 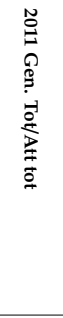 & 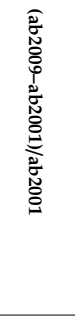 & 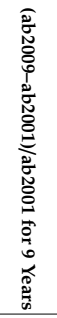 & 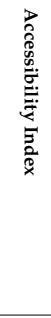 \\
\hline $\begin{array}{l}1 \\
2\end{array}$ & Abbasanta & $1,484,174$ & $\begin{array}{ll}4,440,529 \\
\end{array}$ & 39.9 & 315 & 2640 & 2815 & 2873 & 2877 & 1282 & 1190 & 2338 & 2342 & 1230 & 1050 & 3620 & 3624 & 2420 & 2240 & 70.64 & 72.20 & 0.55 & 1.83 & 0.46 & 0.83 & 1.00 & 1.00 & $6.6 \%$ & 1.034 & 0.882 & 0.414 & 0.428 & 1.171 & 1.08 & $2.2 \%$ & 0.02 & 1.03 \\
\hline & & & 五, & 83.6 & 514 & & 1686 & 1642 & 1629 & 812 & 780 & 44 & & 660 & 213 & & & & 993 & & & 0.56 & & & 0.86 & & & & & & & & & & & & \\
\hline & $\begin{array}{l}\text { Aglientu } \\
\text { Aidmogen }\end{array}$ & $1,512,856$ & $\begin{array}{l}4,550,908 \\
444784\end{array}$ & $\begin{array}{l}148.6 \\
413\end{array}$ & $\begin{array}{l}420 \\
250\end{array}$ & $\begin{array}{l}1102 \\
617\end{array}$ & 1093 & 1198 & 1207 & 526 & 504 & 720 & 646 & 200 & 197 & 1246 & 1172 & 704 & 701 & & 8.12 & 0.73 & 23. & & 0.66 & & & $-0.8 \%$ & & & 0.418 & & 5 & & & 10 & \\
\hline & Aidomaggiore & $\begin{array}{l}1,484,703 \\
152459\end{array}$ & $\begin{array}{l}4,447,784 \\
4501178\end{array}$ & $\begin{array}{l}41.3 \\
188.6\end{array}$ & & 2052 & $\begin{array}{l}542 \\
1949\end{array}$ & $\begin{array}{l}4 / 3 \\
1949\end{array}$ & & 17 & 1048 & & ${ }_{906}^{238}$ & $\begin{array}{l}182 \\
364\end{array}$ & & $\begin{array}{l}522 \\
1978\end{array}$ & $\begin{array}{l}414 \\
1748 \\
178\end{array}$ & $\begin{array}{l}292 \\
1412\end{array}$ & 188 & 13.11 & 11.57 & $\begin{array}{l}0.47 \\
074\end{array}$ & $\begin{array}{l}1.35 \\
1.08\end{array}$ & 0.32 & 0.09 & 1.58 & 1.33 & $12.2 \%$ & & & & & & & $1.8 \%$ & -0.12 & \\
\hline & 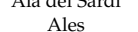 & $\begin{array}{l}1,524,459 \\
1,480,676\end{array}$ & $\begin{array}{l}4,201,1 / 8 \\
4,403,508\end{array}$ & 10 & 4 & 169 & 1628 & 1550 & & 800 & 48 & 48 & $\begin{array}{l}9074 \\
1974\end{array}$ & 376 & 1170 & & 2774 & 11120 & 1156 & $\begin{array}{l}10.33 \\
7520\end{array}$ & $\begin{array}{l}10.41 \\
7081\end{array}$ & $\begin{array}{l}0.74 \\
0.64\end{array}$ & 2.08 & $\begin{array}{l}0.43 \\
0.49\end{array}$ & $\begin{array}{l}0.08 \\
077\end{array}$ & 1.20 & $\begin{array}{l}1.13 \\
074\end{array}$ & $\begin{array}{l}-5.0 \% \\
-3.7 \%\end{array}$ & 7 & & & & & & & 0.01 & \\
\hline 10 & & 1,5 & $\begin{array}{l}4,485800 \\
4\end{array}$ & & 44 & & & & & 31 & & & & 246 & 100 & & & & 342 & & 1926 & $\begin{array}{l}0.04 \\
0.54\end{array}$ & & $\begin{array}{l}0.49 \\
039\end{array}$ & & & & $\begin{array}{l}-3.7 \% \\
-130 \%\end{array}$ & 0.505 & 1.573 & 0.485 & 0.245 & & & & .06 & \\
\hline & & & & & & & 3927 & & & & & & & & 86 & & & & & & & & & & & & & o & 0418 & & & $\begin{array}{l}0.346 \\
0299\end{array}$ & 2.563 & & & -0.13 & \\
\hline 12 & & & 43 & 2672 & 311 & 75 & 7021 & 77 & 9 & 3198 & 2978 & 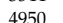 & & 16 & 891 & & & 46 & 3869 & & & 5 & 5 & & & & & & . & & 0.47 & 025 & 187 & $\begin{array}{l}0.894 \\
1.02\end{array}$ & & 0.05 & \\
\hline $1:$ & & & & 381 & 29 & & 847 & 820 & 82 & 452 & 358 & & & $38 \quad$ & & & & & 432 & & & & & 3 & & & & & & 7 & & & & & $\begin{array}{l}-3.2 \% \\
-3.0 \%\end{array}$ & -0.05 & \\
\hline & & & & & $42 \quad-1$ & 352 & 1158 & 1010 & & 20 & & & & 20 & & & & & & & & & & & & & & & & & & & & & & & 2.34 \\
\hline & Armun & & & 54 & $36 \quad$ & & & & & 226 & 1 & & & & & & & & & & & & & & & & & & & & & & & & & & \\
\hline & & & 1 & 16 & 25 & 54 & 48 & 455 & 4 & 88 & & & & 14 & & & & 23 & & & 27.39 & & & & & & & & & & & & 22 & & B\% & & \\
\hline & & & 4, & 35 & 54 & & 1310 & 1238 & 12 & 546 & & & & & & & & 75 & & & & & & & & & & & 0.649 & & & & & & & & \\
\hline & & & & 50 & & & 959 & & & 42 & & & & & & & & & & & & & & & & & & & & & & & & & & & \\
\hline 2 & & & & 30 & 10 & & 1862 & 92 & 18 & 95. & 22 & 88 & 12 & 480 & 342 & & 26 & 15 & & & & & & & & & & & & & & & & & & & \\
\hline 2 & & & & 46.7 & 90 & 10 & 971 & 93 & 90 & 37 & & 640 & $44 \quad 2 \quad$ & 22 & 86 & & & 55 & 414 & & & & & & & & & & & & & & & & & 77 & 2.47 \\
\hline 26 & Banari & $1,472,237$ & $4,495,780$ & 21.3 & 419 & 756 & 677 & 620 & 617 & 224 & 186 & 438 & 256 & 244 & 64 & 662 & 480 & 430 & 250 & 31.83 & 29.01 & 0.51 & 1.14 & 0.33 & 0.65 & 1.71 & .38 & $-10.4 \%$ & .31 & 344 & 0.301 & 1.39: & 3.813 & .72 & $8.9 \%$ & b9 & 1.95 \\
\hline
\end{tabular}




\section{Results}

The cluster analysis and the PCA highlighted a composite system, divided into subsystems, within which the hubs that provide services to the insular territory emerge. The dependencies are not well-defined; they are blurred, especially in the border municipalities. Unlike the Christallerian theory that previously indicated that urban centres are arranged at regular distances for perfect competition, the homogeneity of the territorial areas in the groups formed through the cluster analysis is variable. This observation is evident in Figure 5 where, in addition to the analysis in main components, the level of correlation that each municipality has with the overall tendency of the group to which it belongs is represented.

Moreover, the analysis correctly captures the perimeter of the provincial administrative limits except for some border municipalities which, as already mentioned, are not strongly polarised on a single subsystem. Figure 5, in the three images, shows how each area has a more complex articulation than its administrative boundaries, almost coinciding with the historical areas of Sardinia. It is remarkable to observe how the mathematical analysis, conducted aseptically on the O/D matrix of Istat 2015 mobility, can capture the design of the socio-economic relationships generated by history and orography. Figure 5 shows the results of the cluster analysis, PCA, and the historical regions of Sardinia.

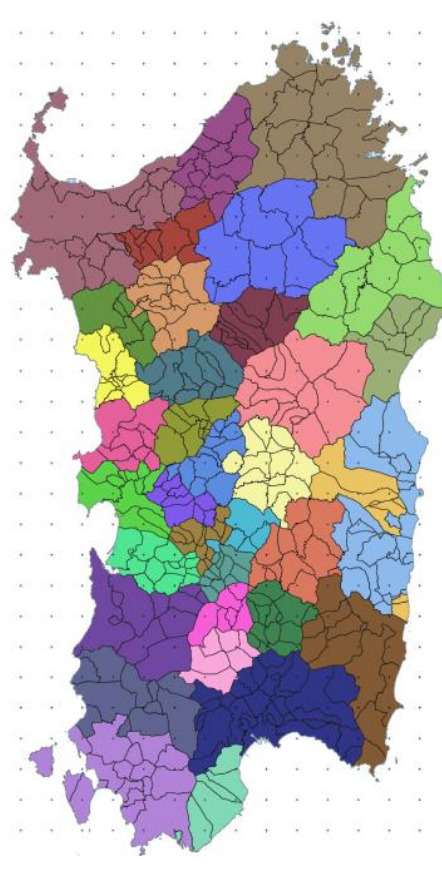

(a)

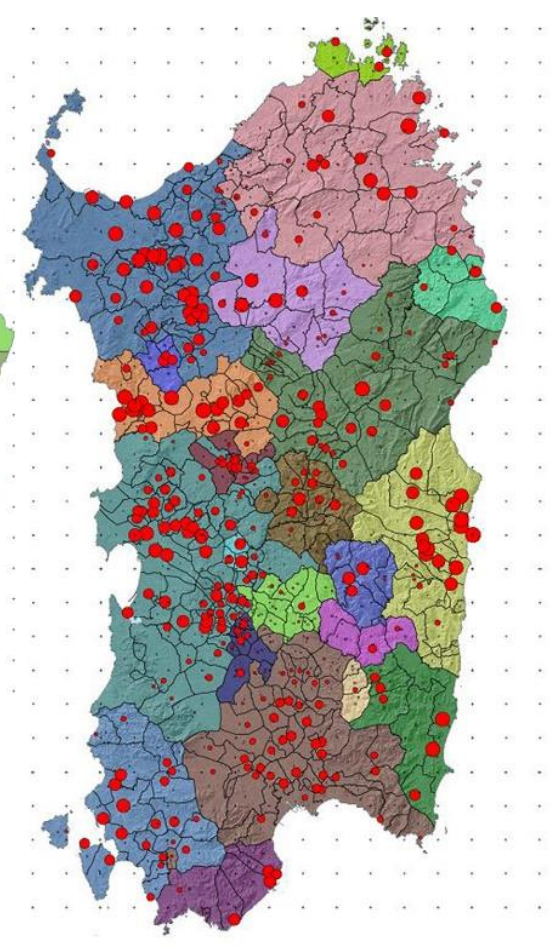

(b)

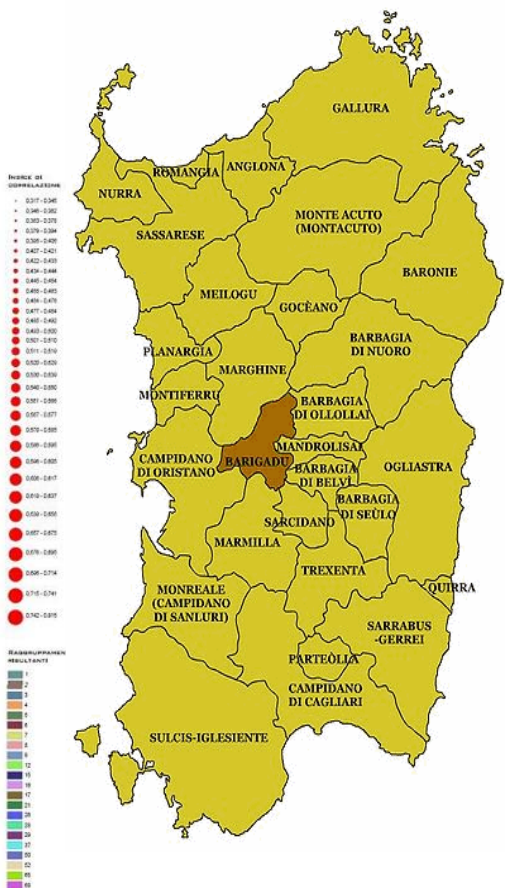

(c)

Figure 5. Results of (a) the cluster analysis; (b) PCA; (c) the historical regions of Sardinia.

The analyses only partially frame the functional dependencies and the coherent behaviour of urban centres, as they refer to the cadenced mobility for study and work reasons. However, this has led to further analysis of the density of the infrastructural endowment to understand how to make inland areas more accessible to coastal areas, which are the areas with the most services. Starting from one of the initial postulates of Chirstaller's central location theory that saw the increase in distance as a real problem for the demand for a service [109], the analysis of the territorial density of the infrastructural endowment shows a limited territorial coverage compared to the Italian average. In particular, the state network is characterised by an infrastructure density that is less than about $20 \%$ of the national one, 
while the provincial one, with a development of $22.63 \mathrm{~km}$ per $100 \mathrm{kmq}$ compared to the national value of $37.81 \mathrm{~km}$ per $100 \mathrm{kmq}$, has a negative gap of $40 \%$.

The part of the territory classified as "mountain" is not considered; the data significantly worsens. In flat and hilly areas, the consistency index of the provincial network is less than half of the national data, while the state network has an index with a negative gap of around $40 \%$. The traditional indexes (network $\mathrm{km}$ per kmq of territory or network $\mathrm{km}$ per inhabitants) used by ISTAT do not allow for highlighting the real criticalities of the regional road network. What makes the situation serious is not so much the overall development but, above all, the standards that it possesses. In the Sardinia region, over $35 \%$ of the road network has sections of less than $7 \mathrm{~m}$ while the national data is $13.5 \%$. Furthermore, road infrastructures with a section of fewer than $9 \mathrm{~m}$ on the island represent $73 \%$, while the national average is $59 \%$. Figure 6a shows the territorial distribution of infrastructures according to their width (including the carriageway, the platforms and the marginal elements). It is significant to observe how the province of Nuoro, historically characterised by minimum accessibility values, is endowed with a considerable development of state and provincial roads; however, these are widely characterized by sections of less than $8 \mathrm{~m}$. The speeds allowed by the current road network are also shown (Figure 6b). It exemplifies, even more clearly, not only the areas of the regional territory in which the most disadvantageous accessibility conditions are verified (Figure 6c) but also the lack of spatial balance, in terms of time and transport costs, which the theory of central places sets as a fundamental principle [110].

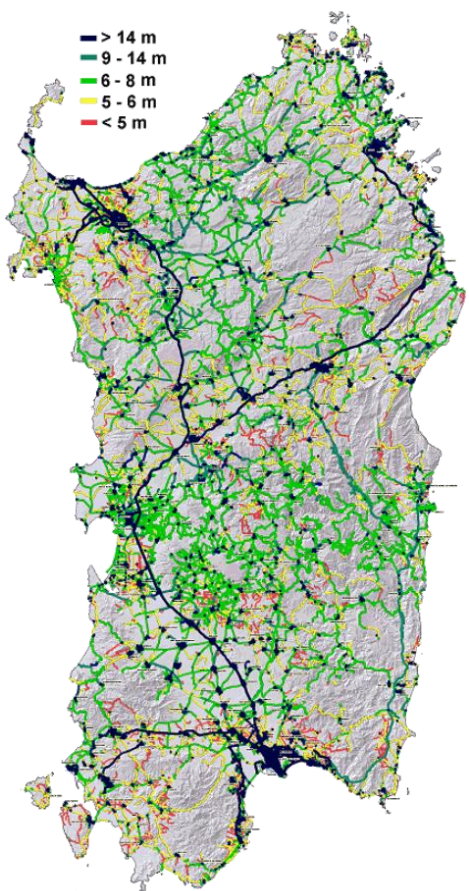

(a)

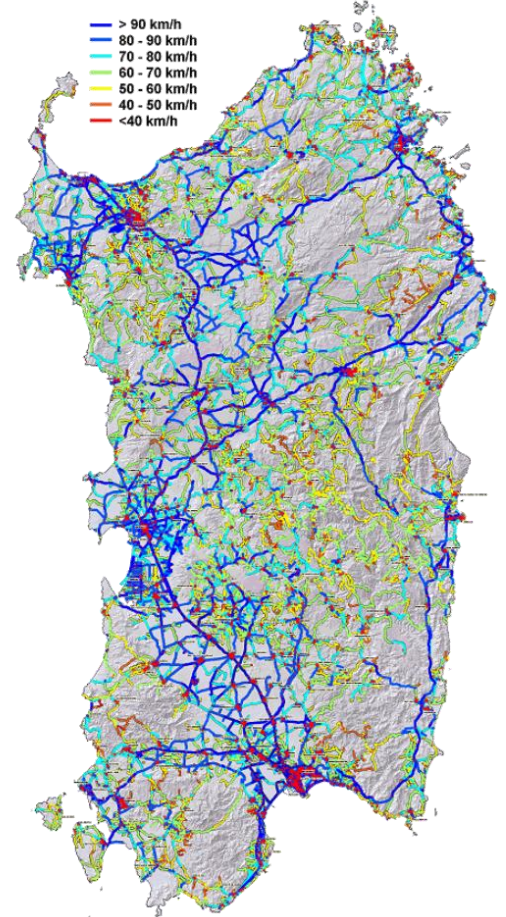

(b)

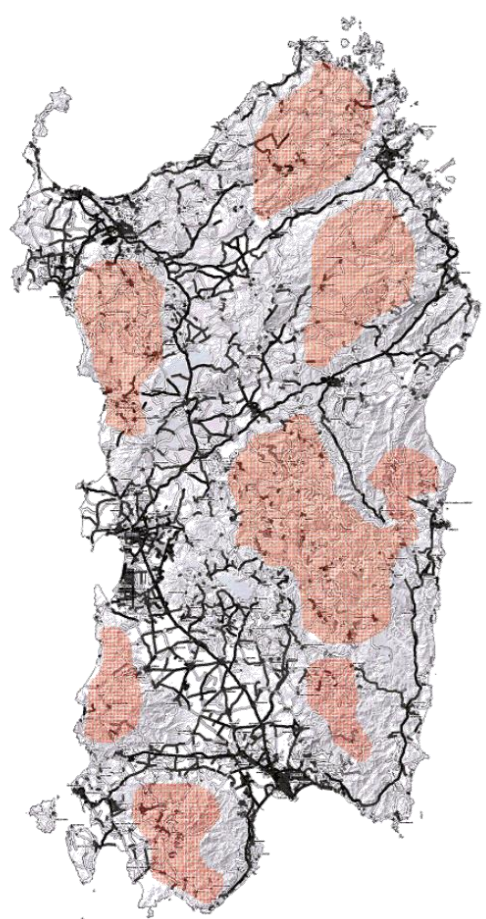

(c)

Figure 6. (a) Distribution of the road network in Sardinia; (b) speed distribution on the road network; (c) areas with inadequate speeds.

Once these analyses were defined, the study analysed the accessibility of the newly defined homogeneous areas regarding the depopulation that particularly affects the internal areas of Sardinia. Figure 7 summarises the results of the analyses. The image shows the depopulation values in percentage terms on the left and the accessibility index on the right. This result was defined as the product of the average times required by each centre to reach the other 377 , and the average altitude above sea level normalised according to the extreme values of depopulation. 
According to this analysis, $68.2 \%$ of the centres are in a phase of depopulation, and about $13.3 \%$ show strong abandonment values, higher than $15 \%$. The most affected centres are in the inner and mountainous part of the island. Moreover, $94 \%$ of the municipalities included in a $10 \mathrm{~km}$ coastal strip have a growing population, and the top 10 coastal centres have growth rates of over $23 \%$.

The comparison between the two images of Figure 7 clearly shows the correlation between the poor conditions of accessibility and high values of decrease. The link between the two indices is non-linear with a correlation coefficient $R=66.5 \%$ and an explained variance of $R 2=44.3 \%$. In other words, the causes of depopulation can be significantly traced to the lack of accessibility.

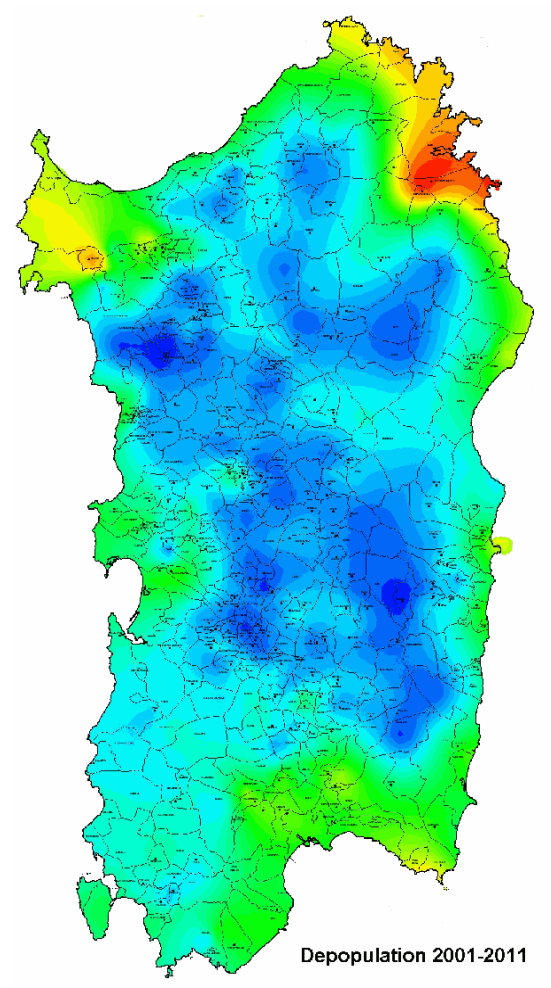

(a)

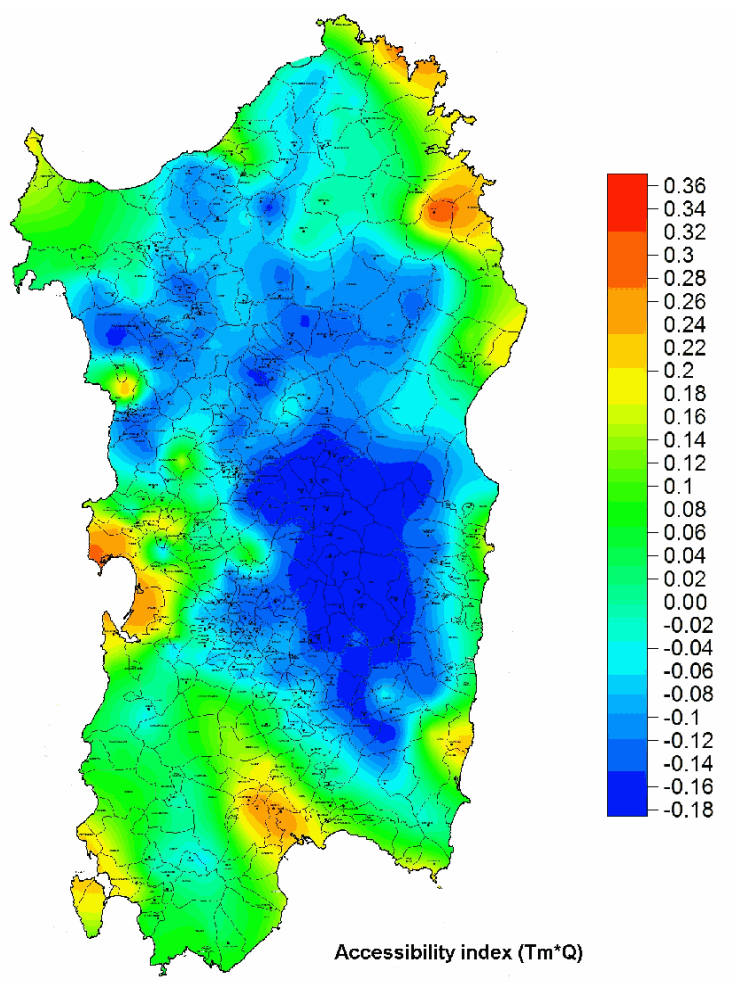

(b)

Figure 7. Results of the conducted analyzes: (a) depopulation values in percentage terms; (b) the accessibility index.

\section{Discussion and Conclusions}

A Smart Governance Strategy is put forward in this study through the union between structural problems common to the islands and the theory of central places; this has allowed for observing how the study of mobility within a closed system (as an island associated with the vocation and needs of the population) is necessary to implement smart territorial policies. First, it was presented theoretically and, subsequently, it was demonstrated through the case study of Sardinia. The CPT (a means to understand the organisational dynamics based on urban hierarchies), which is linked to insularity, leads to reflections on which connection mechanisms are useful in a closed system where the coastal area is different (regarding the economy, morphology, and demography) from the internal area. Furthermore, the case study analysed leads to make some considerations for the major islands. Firstly, this study can make possible the definition of guidelines for the key points of regional island development (as shown in paragraph 3 under the National Strategy of the Italian Areas). In particular, the authors respond to the three points indicated by the National Strategy of the Italian Areas as the basis of development: 
(1) By understanding the attractive force that each region has within it, it is possible to reverse the negative economic and social trend that blocks the development of internal areas. This action can be done by modifying the primary services to change the polycentric articulation of the island territory;

(2) By exploiting the unused internal capital and understanding how to modify the internal attractive force through basic services and the social costs generated by the production and consumption processes;

(3) By understanding that the depopulation phenomena remain one of the most important problems in Sardinia. Reversing the economic trend through the use of inland areas is possible to avoid the depopulation phenomena over time.

The challenge was to understand the strongest urban polarities and the interactions between the geographical areas of the system, which isolates through urban and regional planning data that allowed for developing a smart governance approach to the territory.

Thus, the design of the relationships, which the authors established through the analysis of the main components and the cluster analysis allowed for establishing the presence of stronger areas within the Sardinian insular system, highlighting a spontaneous creation (elaborated from population movements) to groupings of municipalities (of homogeneous areas).

This, at first, allowed for observing how (1) the depopulation phenomena involve the mountain areas to a greater extent than the coastal and flat areas, (2) the outgoing displacements from each municipality can be mainly attributed to the presence of dominant attractors (main urban areas), and (3) the existence of insular subsystems comprises reference hubs and secondary zones.

Furthermore, the analysis, repeatable in other national and international insular contexts, represented the functional dependencies between municipalities; therefore, it is the strength with which the municipalities attract each other. In particular, through the overlap of the Historical Regions of Sardinia and the analysis of the main components, how the homogeneity of the groupings has proved variable and pertinent both to the historical regions and the administrative limits of today became evident.

The result is an organic system composed of the set of identified subsystems that is capable of achieving adequate accessibility conditions throughout the entire regional territory, thereby, making maximum integration between the infrastructural systems, the main vocations of the Sardinian territory (identity, demographic structure, history, culture), and population needs (work, health, services, leisure).

Within each area, the hubs that need to be equipped with services are identified, and, at the same time, how to enhance accessibility within the homogeneous areas and, subsequently, how to improve accessibility between the different areas are studied.

Finally, for further research, this study allowed for having a starting point for developing a set of indicators to identify the polarities that have more services and fewer services, and to define a methodology that can solve similar problems in other insular contexts, considering the dynamics that emerged.

Author Contributions: This paper is the result of the joint work of the authors. In particular, "The analysis of urban polarities to understand the interconnection between inner end coastal areas in insular regions", "The case study of the island of Sardinia in Italy", "Methods", "Application to the case study of Sardinia" and "Results" were written jointly by the authors. C.G. wrote "Introduction", G.D. wrote "Literature review on common issues related to insular regions". M.C. wrote "Discussion and Conclusions". Conceptualization, C.G. and G.D.; data curation, C.G., G.D., and M.C.; formal analysis, C.G.; investigation, M.C.; methodology, C.G., G.D. and M.C.; supervision, C.G. and M.C.; validation, M.C.; writing-original draft, C.G., M.C. and M.C.; writing-review and editing, C.G.

Funding: This study was funded by the MIUR (Ministry of Education, Universities and Research [Italy]) through two projects: (1) Governing the smart city: a governance-centred approach to smart urbanism-GHOST (Project code: RBSI14FDPF; CUP Code: F22I15000070008), financed with the SIR (Scientific Independence of Young Researchers) programme. (2) “CAGLIARI2020" (Project code: PON04a2_00381). We authorize the MIUR to reproduce and distribute reprints for governmental purposes, notwithstanding any copyright notations thereon. Any opinions, findings, and conclusions or recommendations expressed in this material are those of the authors, 
and do not necessarily reflect the views of the MIUR. This study was also supported by the project "Healthy Cities and Smart Territories," founded by the Foundation of Sardinia and Autonomous Region of Sardinia (Fondazione di Sardegna-Convenzione triennale tra la Fondazione di Sardegna e gli Atenei Sardi Regione Sardegna 2016).

Acknowledgments: The authors would like to thank the anonymous reviewers of Sustainability for their valuable contributions and suggestions, which have made possible significant improvements to the text.

Conflicts of Interest: The authors declare no conflict of interest.

\section{References and Notes}

1. Davoudi, S. Understanding territorial cohesion. J. Plan. Pract. Res. 2006, 20, 433-441. [CrossRef]

2. Schön, K.P. Territorial Cohesion-Current Views of the Commission and the Member States of the European Union. Ger. Annu. Spat. Res. Policy 2009, 7-17. [CrossRef]

3. Zaucha, J.; Böhme, K. Measuring territorial cohesion is not a mission impossible. J. Eur. Plan. Stud. 2019. [CrossRef]

4. Medeiros, E. Debating the Urban Dimension of Territorial Cohesion. Territ. Cohes. 2019, 3-22. [CrossRef]

5. Consolidated Version of the Treaty on the Functioning of the European Union, Official EN Journal of the European Union C326/47. 2012. Available online: https://eur-lex.europa.eu/legal-content/EN/TXT/PDF/?uri= CELEX:12012E/TXT\&from=IT (accessed on 17 June 2019).

6. European Structural and Investment Funds Regulations 2014-2020. 2015. Available online: https://ec.europa. eu/regional_policy/en/information/legislation/regulations/ (accessed on 17 June 2019).

7. Methods and Objectives for Effective Use of Community Funds 2014-2020. 2012. Available online: https://www.sicilia-fse.it/Uploads/Temporaneo/Sintesi\%20Doc\%20Barca\%20Metodi-e-obiettivi-per-unuso-efficace-dei-fondi-comunitari-2014-20.pdf (accessed on 17 June 2019).

8. Partnership Agreement 2014-2020 National Strategy for Internal Areas: Definition, Objectives, Tools and Governance. Department for the Development of Social Coesiene. 2013. Available online: file://C:/Users/user/Downloads/Accordo-P-Strategia_nazionale_per_le_Aree_interne_definizione_ obiettivi_strumenti_e_governance_2014\%20 (accessed on 17 June 2019).

9. Coronato, M. The European Instrument to internal areas. Boll. Della Assoc. Ital. Cartogr. 2016, 157, 53-59. [CrossRef]

10. National Strategy for Internal Areas, Department for Planning and Coordination of Economic Policy. Available online: http:/www.programmazioneeconomica.gov.it/2019/05/23/strategia-nazionale-delle-aree-interne/ (accessed on 17 June 2019).

11. Scorza, F.; Murgante, B.; Las Casas, G.; Fortino, Y.; Pilogallo, A. Investigating Territorial Specialization in Tourism Sector by Ecosystem Services Approach. Mediterr. Cities Isl. Communities 2019, 161-179. [CrossRef]

12. The Impact of Cohesion Policies in Europe and Italy. 2018. Available online: http://www.senato.it/service/ PDF/PDFServer/BGT/01083823.pdf (accessed on 15 July 2019).

13. Access to European Union Law. Official Journal of the European Communities C 268 Volume 43. 2000. Available online: https://eur-lex.europa.eu/legal-content/IT/TXT/?uri=OJ\%3AC\%3A2000\%3A268\%3ATOC (accessed on 17 June 2019).

14. Amsterdam Treaty. Available online: http://www.eurotreaties.com/amsterdam-treaty/ (accessed on 17 June 2019).

15. Pan, Y.; Zhai, M.; Lin, L.; Lin, Y. Characterizing the spatiotemporal evolutions and impact of rapid urbanization on island sustainable development. Habitat Int. 2016, 53, 215-227. [CrossRef]

16. Garau, C.; Desogus, G. A preliminary survey for a smart framework for the island contexts. In Proceedings of the IFAU 2018 - 2nd International Forum on Architecture and Urbanism, Pescara, Italy, 8-10 November 2018 (accepted; in press).

17. Priano, F.H.; Armas, R.L.; Guerra, C.F. Developing smart regions: Proposal and application of a model for island territories. Int. J. E Plan. Res. 2018, 7, 89-114. [CrossRef]

18. Smart Islands Declaration, New Pathways for European Islands to Create Smart, Inclusive and Thriving Island Societies for an Innovative and Sustainable Europe. Available online: http://www.smartislandsinitiative.eu/ pdf/Smart_Islands_Declaration.pdf (accessed on 17 June 2019).

19. Smart Islands Projects and Strategies Issued from the 1st European Smart Islands Forum, June 2016, Athens, Greece. Available online: http://library.fes.de/pdf-files/bueros/athen/12860.pdf (accessed on 17 June 2019). 
20. Desogus, G.; Garau, C.; Mistretta, P. Smart Islands: A Systematic Review on Urban Policies and Smart Governance. In Proceedings of the ICCSA 2019-The International conference on computational science and its application, Saint Petersburg, Russia, 1-4 July 2019. (in press).

21. Las Casas, G.; Murgante, B.; Scorza, F. Regional Local Development Strategies Benefiting from Open Data and Open Tools and an Outlook on the Renewable Energy Sources Contribution. Smart Energy Smart City 2016, 275-290. [CrossRef]

22. Stratigea, A.; Papadopoulou, C.A.; Panagiotopoulou, M. Tools and Technologies for Planning the Development of Smart Cities. J. Urban Technol. 2015, 22, 43-62. [CrossRef]

23. State of Implementation of the Public Preliminary Investigation State-Regions/Autonomous Provinces. Available online: http://old2018.agenziacoesione.gov.it/it/arint/Stato_di_attuazione/stato_di_attuazione.html (accessed on 17 June 2019).

24. Sardinia Programming. The Strategy for Internal Areas. Available online: https://www. sardegnaprogrammazione.it/index.php?xsl=1384\&s=278011\&v=2\&c=12950 (accessed on 17 June 2019).

25. Autonomous Region of Sardinia, Resolution n. 6/13 of 10.2.2015. Available online: http://www.regione. sardegna.it/documenti/1_274_20150211164206.pdf (accessed on 17 June 2019).

26. Treaty on European Union. Official Journal of the European Communities No C 191 /3. Available online: https://eur-lex.europa.eu/legal-content/IT/TXT/?uri=CELEX:11992M/TXT (accessed on 13 July 2019).

27. Analysis of the Island Regions and Outermost Regions of the European Union. Available online: https://ec. europa.eu/regional_policy/sources/docgener/studies/pdf/ilesrup/islands_part1_summary_en.pdf (accessed on 13 July 2019).

28. Monfort, P. Territories with Specific Geographical Features. Available online: https://ec.europa.eu/regional_ policy/sources/docgener/work/2009_02_geographical.pdf (accessed on 13 July 2019).

29. The ESPON 2013 Programme the Development of the Islands-European Islands and Cohesion Policy (EUROISLANDS). Available online: https://www.espon.eu/sites/default/files/attachments/inception_report_ full_version.pdf (accessed on 13 July 2019).

30. The Statistical Data of EUROSTAT Is Based on the Definition of Island of the European Community Which Catalogs These as NUTS 3: "Islands Are Defined as Territories Having: A Minimum Surface of $1 \mathrm{~km}^{2}$; a Minimum Distance between the Island and the Mainland of $1 \mathrm{~km}$; a Resident Population of More Than 50 Inhabitants; and No Fixed Link between the Island and the Mainland". Based on the above Definitions, in Europe, There Are Just 76 Insular Regions. EUROSTAT Statistic Explained: Territorial Typologies Manual-Island Regions. Available online: https://ec.europa.eu/eurostat/statistics-explained/index.php?title=Territorial_typologies_manual_ -_island_regions\#Classes_for_the_typology_and_their_conditions (accessed on 16 July 2019). European Parliament, Parliamentary Questions. Available online: http://www.europarl.europa.eu/doceo/document/E8-2018-000443-ASW_EN.html (accessed on 16 July 2019).

31. According to the Final Report on Analysis of the Island Regions of 2000, Europe's Islands are 286 are Home to almost 10 million People Who Occupy an Area of 100,000 Km². Analysis of the Island Regions and Outermost Regions of the European Union. Available online: https:/ec.europa.eu/regional_policy/sources/ docgener/studies/pdf/ilesrup/islands_part1_summary_en.pdf (accessed on 13 July 2019).

32. Annual General Meeting of the CPMR Islands Commission, Corfu (Ionian Islands, Greece). 21 March 2019. Available online: https://cpmr-islands.org/download/final-declaration-adopted-by-the-islands-commissionin-corfu-on-march-2019/?wpdmdl=4650\&ind=1554795693625 (accessed on 16 July 2019).

33. Final declaration approved by the Islands Commission March 21, 2019, 39th Annual General Assembly of the CPMR Islands Commission. 2019. Available online: https://cpmr-islands.org/download/final-declarationadopted-by-the-islands-commission-in-corfu-on-march-2019/?wpdmdl=4650\&ind=1554795700924 (accessed on 15 July 2019).

34. Opinion of the Economic and Social Committee on 'Guidelines for integrated actions on the island regions of the European Union following the Amsterdam Treaty (Article 158), Gazzetta ufficiale dell'Unione europea C 268, il 19/09/2000. Available online: https://eur-lex.europa.eu/legal-content/EN/TXT/?uri=CELEX: 52000IE0805 (accessed on 16 July 2019).

35. Moncada, S.; Camilleri, M.; Formosa, S.; Galea, R. Islands at the Periphery: Integrating the Challenges of Island Sustainability into European Policy. European FP6 Project SENSOR. 2009. Available online: https://www.um.edu.mt/europeanstudies/books/CD_CSP5/pdf/smoncada.pdf (accessed on 28 August 2019). 
36. Pantazis, D.N.; Moussas, V.C.; Murgante, B.; Daverona, A.C.; Stratakis, P.; Nikolaos, V.; Kavadias, A.; Economou, D.; Santimpantakis, K.; Karathanasis, B.; et al. Smart Sustainable Islands vs Smart Sustainable Cities. In Proceedings of the ISPRS Annals of the Photogrammetry, Remote Sensing and Spatial Information Sciences, 2nd International Conference on Smart Data and Smart Cities, Puebla, Mexico, 4-6 October 2017.

37. Dominguez, C.D.; Hernández, M.R.; Talavera, A.S.; López, E.P. Smart Island Tourism and Strategic Marketing: The Case of the Island of El Hierro. Available online: https://pdfs.semanticscholar.org/c411/ 6406d3e277780f018e7d4adee8f27f5c2106.pdf (accessed on 28 August 2019).

38. Banos-González, I.; Martínez-Fernández, J.; Esteve, M.A. Tools for sustainability assessment in island socio-ecological systems: An application to the Canary Islands. Isl. Stud. J. 2016, 11, 9-34. Available online: https://islandstudies.ca/sites/default/files/ISJ-11-1-B-BanosGonz\%C3\%A1lez-et-al.pdf (accessed on 28 August 2019).

39. Abis, E.; Garau, C. An assessment of the effectiveness of strategic spatial planning: A study of Sardinian municipalities. Eur. Plan. Stud. 2016, 24, 139-162. [CrossRef]

40. Tuugalei, I.; Mow, C. Issues and challenges, strategies and recommendations, in the development of ICT in a Small Island Developing State: The case of Samoa. EJISDC 2014, 63, 1-24. [CrossRef]

41. Kurniawan, F.; Adrianto, L.; Bengen, D.G.; Prasetyo, L.B. Patterns of landscape change on small islands: A case of Gili Matra Islands, Marine Tourism Park, Indonesia. Procedia Soc. Behav. Sci. 2016, 227, 553-559. [CrossRef]

42. Lee, Y.B. Exploring the Relationship between E-Government Development and Environmental Sustainability: A Study of Small Island Developing States. Sustainability 2017, 9, 732. [CrossRef]

43. Castanho, R.A. Dynamics of the Land Use Changes and the Associated Barriers and Opportunities for Sustainable Development on Peripheral and Insular Territories: The Madeira Island, Portugal. 2018. Available online: https://www.intechopen.com/online-first/dynamics-of-the-land-use-changes-and-the-associatedbarriers-and-opportunities-for-sustainable-devel (accessed on 28 August 2019).

44. Sánchez, A.F.; Gil, F.S.; Sabater, L.A.; Dentinho, T.P. AQ Methodology approach to define urban sustainability challenges in a small insular city. In Proceedings of the 51st European Congress of the Regional Association International, Barcelona, Spain, 30 August-3 September 2011.

45. Andriotis, K. Researching the development gap between the hinterland and the coast-Evidence from the island of Crete. Tour. Manag. 2006, 27, 629-639. [CrossRef]

46. Papatheochari, T.; Coccossis, H. Development of a waterfront regeneration tool to support local decision making in the context of integrated coastal zone management. Ocean Coast. Manag. 2019, 169, $284-295$. [CrossRef]

47. Vallega, A. Urban waterfront facing integrated coastal management. Ocean Coast. Manag. 2001, 44, 379-410. [CrossRef]

48. Novembre, C. Le aree interne della sicilia tra problemi di sviluppo e ricomposizione territorial. Geogr. Ital. 2015, 122, 235-253. Available online: https://dialnet.unirioja.es/servlet/articulo?codigo=5173381 (accessed on 26 July 2019).

49. Core, B. Spatial dynamics of Mediterranean coastal regions. J. Coast. Conserv. 1999, 5, 105-112. Available online: https://link.springer.com/content/pdf/10.1007\%2FBF02802747.pdf (accessed on 26 July 2019).

50. Internal Areas: Which Territories Are We Talking About? Explanatory Note on the Method of Classifying Areas. Available online: http://old2018.agenziacoesione.gov.it/opencms/export/sites/dps/it/documentazione/ Aree_interne/Nota_metodologica_Aree_interne.pdf (accessed on 15 July 2019).

51. Mulligan, G.F.; Partridge, M.D.; Carruthers, J.I. Central place theory and its reemergence in regional science. Ann. Reg. Sci. 2012, 48, 405-431. [CrossRef]

52. Doran, D.; Fox, A. Operationalizing Central Place and Central Flow Theory with Mobile Phone Data. Ann. Data Sci. 2015, 3, 1-24. [CrossRef]

53. Berry, B.J.I.; Baskin, C.W.; Christaller, W. Central Places in Southern Germany. Econ. Geogr. 1967, 43, $275-276$. [CrossRef]

54. Woglom, H.W.; Stolper, W.F. The Economics of Location by August Lösch. Am. Sociol. Rev. 1995, 20, 370-361. [CrossRef]

55. Getis, A.; Getis, J. Christaller's Central Place Theory. J. Geogr. 1966. [CrossRef]

56. Fujita, M.; Ogawa, H.; Thisse, J.F. A spatial competition approach to central place theory: Some basic principles. J. Reg. Sci. 1988, 28, 477-494. [CrossRef] 
57. Ye, X.; Liu, X. Cities as Spatial and Social Networks, 1st ed.; Springer: Cham, Switzerland, 2019; p. 41, ISBN 978-3-319-95350-2.

58. Clark, J.; Harrison, J.; Miguelez, E. Connecting cities, revitalizing regions: The centrality of cities to regional development. Reg. Stud. 2018, 52, 1025-1028. [CrossRef]

59. Knitter, D.; Nakoinz, O. The Relative Concentration of Interaction-A Proposal for an Integrated Understanding of Centrality and Central Places. Land 2018, 22-39, 86. [CrossRef]

60. Hsu, W.T.; Zou, X. Central Place Theory and the Power Law for Cities. Math Urban Morphol. 2019, 55-75. [CrossRef]

61. Derudder, B.; Taylor, P.J. Central flow theory: Comparative connectivities in the world-city network. Reg. Stud. 2018, 52, 1029-1040. [CrossRef]

62. Malý, J. Polycentric Urban Systems and Territorial Cohesion. In Territorial Choesion the Urban Dimension, 1st ed.; Springer: Cham, Switzerland, 2019; p. 41, ISBN 978-3-030-03386-6.

63. Camagni, R. From city hierarchy to city network: Reflections about an emerging paradigm. In Seminal Studies in Regional and Urban Economics: Contributions from an Impressive Mind; Springer: Cham, Switzerland, 2017. [CrossRef]

64. Krugman, P. Increasing Returns and Economic Geography. J. Polit. Econ. 1991, 99. [CrossRef]

65. Von Böventer, E. Toward a united theory of spatial economic structure. Pap. Reg. Sci. 1962, 10, $163-187$. [CrossRef]

66. Pred, A. The Interurban Transmission of Growth in Advanced Economies: Empirical Findings Versus Regional-Planning Assumptions. Reg. Stud. 1976, 10, 151-171. [CrossRef]

67. Davoudi, S. Polycentricity in European spatial planning: From an analytical tool to a normative agenda. Eur. Plan. Stud. 2003, 11, 979-999. [CrossRef]

68. Van Meeteren, M.; Poorthuis, A. Christaller and "big data": Recalibrating central place theory via the geoweb. Urban Geogr. 2018, 39, 122-148. [CrossRef]

69. Chapman, G.P. The Application of Information Theory to the Analysis of Population Distributions in Space. Econ. Geogr. 2006, 46, 317-331. [CrossRef]

70. Mulligan, G.F. Agglomeration and Central Place Theory: A Review of the Literature. Int. Reg. Sci. Rev. 1984, 9, 1-42. [CrossRef]

71. Parr, J.B. Competition, supply areas and industrial location: An equilibrium perspective. Ann. Reg. Sci. 1993, 27, 191-210. [CrossRef]

72. Loumeau, G. Locating Public Facilities: Theory and Micro Evidence from Paris; KOF Working Papers; KOF Swiss Economic Institute: Zurich, Switzerland, 2019; Volume 452. [CrossRef]

73. Godwin Onokerhoraye, A.G. A conceptual framework for the location of public facilities in the urban areas of developing countries: The Nigerian case. Socio Econ. Plan. Sci. 1976, 10, 237-240. [CrossRef]

74. Teitz, M.B. Toward a theory of urban public facility location. Pap. Reg. Sci. Assoc. 1968, 21, 35-51. [CrossRef]

75. Beckmann, M.J.; Thisse, J.F. The location of production activities. Handb. Reg. Urban Econ. 1987, 1, $21-95$. [CrossRef]

76. Jovanovic, M.N. Spatial Location of Firms and Industries: An Overview of Theory. Econ. Internazionale 2003, 56, 23-82. [CrossRef]

77. Xu, F.; Zhen, F.; Qin, X.; Wang, X.; Wang, F. From central place to central flow theory: An exploration of urban catering. Tour. Geogr. 2019, 21, 121-142. [CrossRef]

78. Butowski, L. Tourist sustainability of destination as a measure of its development. Curr. Issues Tour. 2017, 22, 1043-1061. [CrossRef]

79. Daniels, M.J. Central place theory and sport tourism impacts. Ann. Tour. Res. 2007, 34, 332-347. [CrossRef]

80. Brown, S. Christaller Knew My Father: Recycling Central Place Theory. J. Macromarketing 1995, 15, 60-72. [CrossRef]

81. Dennis, C.; Marsland, D.; Cockett, T. Central place practice: Shopping centre attractiveness measures, hinterland boundaries and the UK retail hierarchy. J. Retail. Consum. Serv. 2002, 9, 185-199. [CrossRef]

82. Stratigea, A.; Katsoni, V. A strategic policy scenario analysis framework for the sustainable tourist development of peripheral small island areas-The case of Lefkada-Greece Island. Eur. J. Futures Res. 2015, 3. [CrossRef]

83. Choy, D.J.L. Life Cycle Models for Pacific Island Destinations. J. Travel Res. 1992, 30, 26-31. [CrossRef]

84. Fennell, A.F. A tourist space-time budget in the Shetland Islands. Ann. Tour. Res. 1996, 24, 811-829. [CrossRef] 
85. Rodríguez, J.R.O.; Parra-López, E.; Yanes-Estévez, V. The sustainability of island destinations: Tourism area life cycle and teleological perspectives. The case of Tenerife. Tour. Manag. 2008, 29, 53-65. [CrossRef]

86. Nguyen, D.N.; Imamura, F.; Iuchi, K. Barriers towards hotel disaster preparedness: Case studies of post 2011 Tsunami, Japan. Int. J. Disaster Risk Reduct. 2018, 28, 585-594. [CrossRef]

87. Volgmann, K.; Rusche, K. The Geography of Borrowing Size: Exploring Spatial Distributions for German Urban Regions. Early View 2019. [CrossRef]

88. Van Meeteren, M. Urban System. In The Wiley Blackwell Encyclopedia of Urban and Regional Studies; John Wiley \& Sons, Ltd.: Hoboken, NJ, USA, 2019. [CrossRef]

89. Mulíček, O.; Malý, J. Moving towards more cohesive and polycentric spatial patterns? Evidence from the Czech Republic. Reg. Sciance 2019, 98, 1177-1194. [CrossRef]

90. Mitchell, R.E. Individual Settlements Are Members of Larger Settlement Systems. In Human Geographies within the Pale of Settlement, 1st ed.; Mitchell, R.E., Ed.; Palgrave Macmillan: Cham, Switzerland, 2018; pp. 71-91, ISBN 978-3-319-99144-3.

91. Lenormand, M.; Ramasco, J.J. Towards a Better Understanding of Cities Using Mobility Data. Built Environ. 2016, 42, 356-364. [CrossRef]

92. Hansen, N. Border regions: A critique of spatial theory and a European case study. Ann. Reg. Sci. 1977, 11, 1-14. [CrossRef]

93. Azzari, M.; Garau, C.; Nesi, P.; Paolucci, M.; Zamperlin, P. Smart City Governance Strategies to better move towards a Smart Urbanism. Comput. Sci. Its Appl. ICCSA 2018, 10962, 639-653. [CrossRef]

94. Demographic Statistics, Population Sardinia 2001-2018. Available online: https://www.tuttitalia.it/sardegna/ statistiche/popolazione-andamento-demografico/ (accessed on 23 June 2019).

95. Italian Regions Classified by Area. Available online: https://www.tuttitalia.it/regioni/superficie/ (accessed on 23 June 2019).

96. Regional law 4 February 2016, n. 2. Reorganization of the system of local autonomies of Sardinia. Official bulletin of the Sardinia region n. 6 of 11 February 2016.

97. ISTAT. Statistical Codes of Territorial Administrative Units: Municipalities, Metropolitan Cities, Provinces and Regions. Available online: https://www.istat.it/it/archivio/6789\# Elencodeicodiciedelledenominazionidelleunitterritoriali-0 (accessed on 23 June 2019).

98. CRENOS. Economy of Sardinia, 25th Report 2018. Available online: http://crenos.unica.it/crenosterritorio/ sites/default/files/allegati-pubblicazioni-tes/Economia\%20della\%20Sardegna\%20-\%2025\%C2\%B0\% 20Rapporto\%20CRENoS\%202018.pdf (accessed on 15 July 2019).

99. Fisale, K.; Shaker, A. An Investigation of GIS Overlay and PCA Techniques for Urban Environmental Quality Assessment: A Case Study in Toronto, Ontario, Canada. Sustainability 2017, 9, 380. [CrossRef]

100. Li, X.; Gar-On Yeh, A. Urban Simulation Using Principal Components Analysis and Cellular Automata for Land-Use Planning. J. Photogramm. Eng. Remote Sens. 2002, 68, 341-351.

101. Li, X.; Gar-On Yeh, A. Principal component analysis of stacked multi-temporal images for the monitoring of rapid urban expansion in the Pearl River Delta. Int. J. Remote Sens. Taylor Fr. 1998, 19, 1501-1518. [CrossRef]

102. Pacione, M. Urban environmental quality and human wellbeing-a social geographical perspective. J. Landsc. Urban Plan. 2003, 65, 19-30. [CrossRef]

103. Bonaiuto, M.; Fornara, F.; Bonnes, M. Indexes of perceived residential environment quality and neighbourhood attachment in urban environments: A confirmation study on the city of Rome. J. Landsc. Urban Plan. 2003, 65, 41-52. [CrossRef]

104. Everitt, B.S.; Landau, S.; Leese, M.; Stahl, D. Cluster Analysis, 5th ed.; John Wiley \& Sons: Hoboken, NJ, USA, 2011; ISBN 9780470749913.

105. Jolliffe, I. Principal Component Analysis. In International Encyclopedia of Statistical Science, 1st ed.; Lovric, M., Ed.; Springer: Berlin/Heidelberg, Germany, 2011. Available online: https://link.springer. com/referenceworkentry/10.1007\%2F978-3-642-04898-2_455 (accessed on 15 July 2019).

106. Krzanowski, W. Principles of Multivariate Analysis, 2nd ed.; Oxford University Press: Oxford, UK, 2000; ISBN 978-0-19-850708-6.

107. Cormen, T.H.; Leiserson, C.E.; Rivest, R.L.; Stein, C. Introduction to Algorithms, 2nd ed.; The MIT Press: Cambridge, MA, USA, 2001; ISBN 0-262-03293-7. 


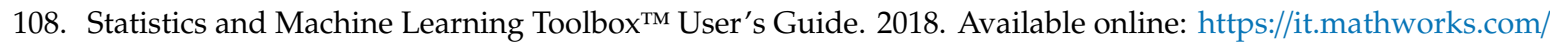
help/pdf_doc/stats/stats.pdf (accessed on 26 July 2019).

109. Parr, J.B. Central place theory: An evaluation. Rev. Urban Reg. Dev. Stud. 2017, 11, 256-14. [CrossRef]

110. Spatial Balance and Central Locations, Lesson 4. Available online: http://www.gpt.adhoc.ch/Geoeconomica/ Modulo2/Lezione4.pdf (accessed on 23 June 2019). 